\title{
Article
}

\section{The Impact of Public Administration Digitalization on the Decarbonization of the Economy}

\author{
Aleksander Jakimowicz ${ }^{1, *(1)}$ and Daniel Rzeczkowski ${ }^{2}$ \\ 1 Department of World Economy, Institute of Economics, Polish Academy of Sciences, Palace of Culture and \\ Science, 1 Defilad Sq., 00-901 Warsaw, Poland \\ 2 Department of Market and Consumption, Institute of Economics and Finance, Faculty of Economic Sciences, \\ University of Warmia and Mazury in Olsztyn, 1/327 Cieszyński Sq., 10-720 Olsztyn, Poland; \\ daniel.rzeczkowski@uwm.edu.pl \\ * Correspondence: ajakimowicz@inepan.waw.pl
}

Citation: Jakimowicz, A.;

Rzeczkowski, D. The Impact of Public Administration Digitalization on the Decarbonization of the Economy. Energies 2021, 14, 5739. https:// doi.org/10.3390/en14185739

Academic Editor:

Praveen Cheekatamarla

Received: 3 July 2021

Accepted: 8 September 2021

Published: 12 September 2021

Publisher's Note: MDPI stays neutral with regard to jurisdictional claims in published maps and institutional affiliations.

Copyright: (c) 2021 by the authors. Licensee MDPI, Basel, Switzerland. This article is an open access article distributed under the terms and conditions of the Creative Commons Attribution (CC BY) license (https:/ / creativecommons.org/licenses/by/ $4.0 /)$.
Abstract: According to wikinomics, the decarbonization of the economy it is not possible without the involvement of people's creativity and ingenuity under the form of prosumption channeled into the public administration. In order to achieve this goal, it is necessary to transform the existing websites of municipal offices into participation platforms that would become the local growth poles concentrating the economic forces operating in a given area. As Adam Smith, the father of economics, noted, synchronization between the economic goals of people and the preferences of local authorities are the main factors of development and the lack of them can create the highest degree of chaos in the economy. Consequently, the research began with defining prosumption and determining the degree of cooperation between society and the public administration sector in the digital sphere. Correspondence analysis was used to analyze the data collected from a survey. The issue of the quality of websites of municipal public administration offices, which in the digital economy function as growth poles and development axes, was also discussed. It was observed that society is prepared to perform the role of prosumers in the public administration sector; however, the low quality of websites constrains full disclosure of society's prosumer potential. Under these conditions, the best ways to decarbonize the local economy are: (1) acceleration of the digitization of municipal public administration; and (2) use of the already existing infrastructural growth poles and development axes. The first postulate is related to the improvement of the existing, and the construction of new, computer networks. The second point mainly concerns the achievements of molinology, which studies the existing and partially functional infrastructure of former watermills and the location of former windmills. It is a valuable clue that facilitates the location and construction of modern renewable energy sources. The subject of the research is the Warmia and Mazury Province, which includes 116 municipalities and is the fourth largest province in Poland.

Keywords: public administration digitalization; prosumption; platforms for participation; correspondence analysis; computer networks; historically and politically conditioned infrastructural growth poles; Warmia and Mazury Province; decarbonization of the economy; renewable energy sources; molinology

\section{Introduction}

The need to decarbonize national economies results from the unfavorable climate changes that have occurred in the world in recent decades. The main reason for these changes is the growing emission of carbon dioxide $\left(\mathrm{CO}_{2}\right)$ into the Earth's atmosphere, which is interpreted as a by-product of human economic activity. Under the Paris Agreement, adopted on 12 December 2015, the international community has committed to limiting the increase of global average temperature to below $2{ }^{\circ} \mathrm{C}$ above a pre-industrial baseline and attempting to reduce this increase to $1.5^{\circ} \mathrm{C}$ [1]. On 10 February 2021, 195 countries were signatories, and 190 were parties [2]. The goal formulated in the Paris Agreement 
can be achieved by introducing new technologies to reduce $\mathrm{CO}_{2}$ emissions, increasing the share of renewable energy sources in total energy production and through the strategy of climate neutrality, which consists of balancing the inevitable $\mathrm{CO}_{2}$ emissions with its absorption, mainly by forests. On 20 June 2019 Poland, with the support of the Czech Republic, Hungary and Estonia, blocked the European Union's decision to pursue energy neutrality by 2050 [3]. In December 2019, the European Council approved the goal of achieving the neutrality within the prescribed period, while maintaining the exemption for Poland [4]. In recent months, Poland has reconsidered the possibility of achieving climate neutrality by 2050, but it was also emphasized that such an energy transition would be costly and would require at least 68.5 billion EUR. Currently, 75\% of electricity demand in Poland is covered by coal-fired power plants [5].

Informally, the program for the development of renewable energy sources in Poland was formulated in 1982 in the drama film Gwiezdny Pyt (Stardust), directed by Andrzej Kondratiuk [6]. In 1984, the film was nominated for the Grand Prix Golden Lion at the Polish Film Festival in Gdańsk. Despite its great popularity, this film did not win the main prize, but it was awarded with the Special Jury Prize. The main character-the Old Man (Stary), played by Krzysztof Chamiec_-builds a small hydroelectric power plant. In a conversation with a neighbor, he diagnoses the main cause of global warming in the following way: I can see that it is due to the pollution, the terrible dustiness. Today, man releases too much smoke into the air, soot falls to the ground, it falls on glaciers, glaciers get dirty, dusty and begin to absorb the sun's rays; ice heats up and starts to melt and melts, everything melts; cold water flows from it into the ocean, it spills over the entire globe, the water carries a chill and as a result it sucks ... After some time, the Old Man is summoned to the local government office to determine the amount of tax related to the operation of the power plant. Then he utters the following words: if they wanted to understand that instead of looking for krill somewhere in the oceans, it would be enough to put a carp into all our waters; that where the river flows, there is a current; that where there is a shortage of fruit, trees must be planted; that where a thousand people eat there is swill and a thousand pigs can be fed. At one point, the Old Lady (Stara) - the Old Man's wife-asks him the following question: couldn't you do something such that what a man thinks could happen and it would happen? The Old Man replies: there is no patent for it; yeah ... well, that would be a great invention ... And you know I'll try. Thought is alternating current and current is electrons. If the voice could be strengthened, then the thought could be intensified. In order to implement his plan, the Old Man goes to the junkyard, where he finds a vacuum tube superheterodyne receiver, which he uses to build a device that amplifies human thoughts and transforms them into radio waves. This device is powered by electricity from the previously built small hydropower plant. Strengthened and sent into the ether is, among others, the following thought of the Old Lady: that man should stop destroying ... [6]. It is literally today's low-carbon economy development program adopted by the European Union, which was launched 33 years before the Paris Agreement on climate change.

The words spoken by the protagonist of the mentioned film, if they wanted to understand, are the essence of what we now call prosumption in public administration. It is about integrating people's natural creativity and ingenuity into this ossified and very often overly bureaucratic sector of the economy. The process of decarbonizing the economy begins in municipalities, which are the basic units of the local government. The public administration offices operating in their area have a decisive role in the development of municipalities. The use of opportunities offered by information technologies, reflected in the digitization of public administration, is one of the strategies of energy transformation aimed at building the low carbon economy. In this way the postulates of wikinomics are implemented, that is, the introduction of business models such as prosumption or participation platforms into this sector. Indeed, by prosumption in a broader sense, we can understand the principle introduced by the pioneer of economics, Adam Smith [7] (p. 275), which indicates that the economic policy of the state should not contradict the natural creativity of the people. Otherwise in the economy one should expect the highest degree of disorder. In this way 
we are forced today to return to the beginnings of economics as a science, to take the trouble of rewriting it. Digitization of public administration is very important as it enables the creation of participation platforms, that is, advanced websites of municipal offices, where communities could present detailed prosumer solutions for decarbonizing the local economy and decide on actions to be taken in the area together with the authorities. This is the only possible path to sustainable development as it removes the conflicts predicted by Adam Smith. Therefore, all considerations regarding the decarbonization of the economy should be preceded by the determination of the degree of compliance of the prosumer attitudes of society with the expectations of public administration.

The main aim of the article is to show that the digitization of public administration is a key factor in decarbonizing the Polish economy. This is particularly applicable to the Warmia and Mazury Province, which is analyzed in greater detail. Obtaining electricity from renewable sources on a larger scale requires close cooperation of municipal public administration offices, which are the basic units of local government, with residents, enterprises and other economic institutions. The decarbonization of the economy starts in municipalities and requires the involvement of local communities in the process [8]. According to wikinomics, the creation of modern municipal websites-called participation platforms-would allow for the employment of the natural ingenuity and creativity of society for the purpose of decarbonization. This phenomenon is called prosumption. The digitalization of the knowledge obtained in this form facilitates its processing and application. It will be presented that digital prosumption is an opportunity to increase the production of electricity from renewable sources in Warmia and Mazury.

The article focuses on the development of renewable energy in Warmia and Mazury, because from the point of view of achieving climate neutrality by 2050, this region is of particular importance not only for Poland, but also for neighboring states. The province is one of the least economically developed regions in the country, and at the same time is an importer of electricity from distant coal-fired power plants, which significantly increases the costs of electricity transmission. Moreover, the region is extremely valuable in terms of environment due to the existence of many nature reserves, landscape parks, unique fauna and flora habitats as well as tourist and recreational facilities. This excludes the possibility of building larger power plants in the area. Low density of power lines is another feature of the region. For these reasons, it is planned to develop a network of small power plants based on renewable energy sources such as water and wind. The undoubted advantage of Warmia and Mazury is the large area of forests, which absorb carbon dioxide in the process of photosynthesis. This is an important factor that may help Poland achieve climate neutrality by 2050. Due to this feature of the region, similar benefits may be gained by neighboring countries such as Lithuania, Russia and Belarus.

Another problem that may inhibit regional economic development and decarbonization processes is the delay of the public administration sector compared to the market sector in implementing wikinomics' business patterns. Therefore, this paper also attempts to explain the causes of asymmetry in the development of market sectors and public administration sector in the Warmia and Mazury economy. The opinions of respondents who were clients of municipal public administration offices helped to determine the importance of the different principles of prosumption depending on respondents' age and sex. In addition, the possibility of transforming the websites of offices into modern platforms for participation has been investigated, which is the condition of introduction of prosumption and other wikinomics patterns in the public administration sector.

The research shows that the prosumption model is the most appropriate method to obtain electricity from renewable sources in Warmia and Mazury. There are many reasons for this. The area is geographically very diverse, it contains many valuable natural objects and it is also of great tourist importance which rather excludes the construction of larger power plants. For this reason, the best direction to decarbonize the economy in this region is to build small power plants using solar, wind, water, biomass and biogas energy. Therefore, public administration and its digitization are of key importance in this 
case. Statistical research shows that, so far, the public administration is poorly prepared to support the prosumption model. Rapid digitization of public administration would increase the chances to support local prosumers producing electricity from renewable sources and thus to reduce carbon dioxide emissions to the atmosphere. In line with the research hypothesis adopted in the article, the use of prosumption in Warmia and Mazury is the main economic force capable of ensuring full decarbonization of the regions' local economy and contributing to the achievement of this goal throughout the country.

\section{Research Plan on the Connection between Digitization of Public Administration and Decarbonization of the Economy}

The relationships between the digitization of public administration and the decarbonization of the economy are of great importance in contemporary capitalism, although they have not been the subject of a broader scientific discussion so far. This important problem was noticed during the evaluation of the websites of municipal public administration offices in the context of the development of green energy in Warmia and Mazury. This initiated a series of additional studies that formed the basis of this article. Figure 1 shows the transformation of the renewable energy sector in Warmia and Mazury in the process of economic system development from producer and consumer capitalism to the prosumer capitalism.

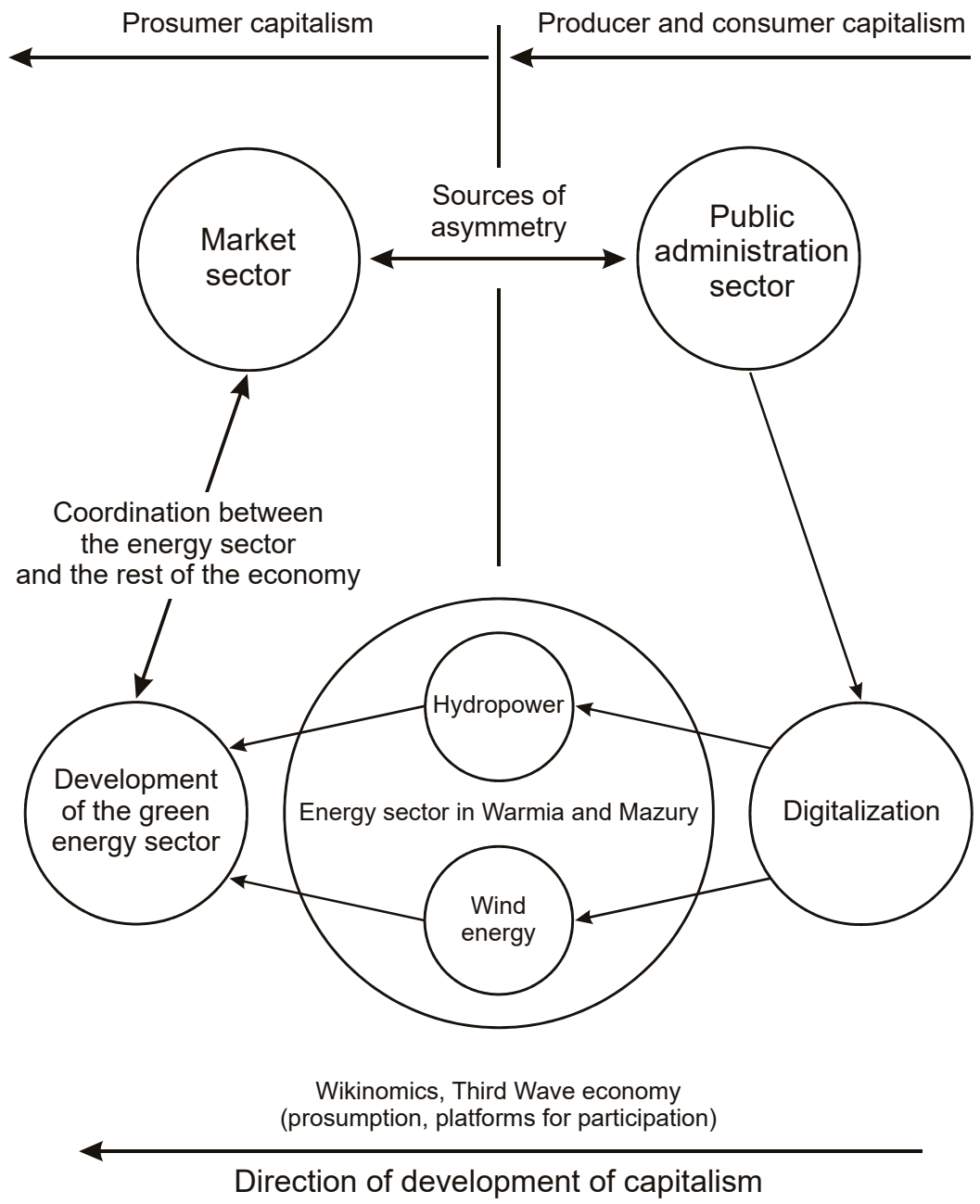

Figure 1. Transformation of the renewable energy sector in Warmia and Mazury in the process of transition from producer and consumer capitalism to the prosumer capitalism.

In recent decades, as a result of the development of information technology, the traditional economy has transformed into a digital economy, where the flow of information 
in computer networks has become the basis for production, trade and payment transactions. The real and financial sectors and their relationships have changed significantly. New, previously unknown business models appeared, such as digital prosumption or platforms for participation, which very quickly found application in the market sector. The need for their scientific description led to the emergence of an interesting stream of research in economics called wikinomics, and the economy emerging from these changes was called the Third Wave economy. It was quickly noticed that wikinomics' business patterns contributed to the significant development of the market sector, however, some sectors, such as public administration, lagged far behind. The resulting disproportions hindered further sustainable development of the digital economy.

Figure 1 shows schematically the relationship between the digitization of the public administration sector and the development of the green energy sector in Warmia and Mazury. The widespread application of wikinomics business patterns in the real and financial sectors and the emergence of the Third Wave economy changed the face of modern capitalism. The new type of economic system has been called prosumer capitalism because it is characterized by the fusion of production and consumption into a single process called prosumption. This form of capitalism differs significantly from its earlier forms, that is, producer and consumer capitalism, in which production and consumption were separate phenomena. As previously mentioned, the uneven absorption of information technologies signified that the market sector was included in the prosumer capitalism as a result of its rapid development, while the public administration sector remained almost unchanged, as it had in producer and consumer capitalism. This has resulted in the emergence of asymmetry between these sectors, and one of its effects is the inhibition of the development of the renewable energy sector, in particular, hydro and wind energy, which we will analyze in greater detail.

The elimination of the asymmetry presented in Figure 1 requires the use of wikinomics business patterns, such as prosumption and platforms for participation in the public administration sector, thus adjusting this sector to the requirements of the prosumer capitalism. This would shift the sector to the left towards the market sector. The disproportion between the market and public administration inhibits the development of the entire economy, however, in this work, we will only consider the impact on the development of the green energy sector.

The factors initiating the development of hydropower and wind energy are market forces and the commonly known need to reduce carbon dioxide emissions to the atmosphere, however, numerous administrative barriers effectively hinder and delay the commissioning of the power stations. For this reason, the energy sector is on the border between the prosumer capitalism and its earlier forms in the shape of producer and consumer capitalism. Due to its geographical diversity and the need to protect the environment, the development of the renewable energy sector in the analyzed region is possible only in the prosumption model, in which small hydro and wind power stations function perfectly. Currently in order to obtain a permit for this type of activity, prosumers are faced with a long and burdensome procedure in the public administration offices which is against the expectations of prosumers who, ask for swift and efficient service that is in line with the new type of economy. The main factor that could accelerate the process is the digitization of the public administration sector, therefore its adjustment to the requirements of the prosumer capitalism. It would certainly accelerate the development of diversified hydro and wind energy. In this way, the sources of asymmetry between the real and the regulatory spheres would be removed, and thus the degree of coordination between the market sector and the renewable energy sector would increase.

The starting point for the research is the evaluation of the websites of municipal public administration offices by the society of Warmia and Mazury and the determination of whether these websites can act as participation platforms and enable the use of the prosumption potential of society in order to accelerate the decarbonization of the economy. The digitization of public administration signifies the adaption of this sector to the 
requirements of prosumption capitalism, which establishes appropriate conditions for the functioning of small hydro and wind power stations. The research plan presented in Figure 1 is discussed in detail in the following parts of the article.

The fundamental problem investigated in this paper concerns the relationship between the digitization of the public administration sector at the local level and the decarbonization of the regional economy. This issue has been already quite widely explored in the literature on wikinomics, where basic operating principles and business models that need to be adapted in the public administration sector have been formulated $[9,10]$. Without this, the public sector cannot succeed with the energy transition. Nevertheless, while the relationships between digitization and decarbonization have been recognized on theoretical grounds, there has been no convincing empirical evidence to confirm them so far. We set out to change that, and in our article, for the first time in the literature, we present strong empirical evidence for the relationship between digitization and decarbonization. However, this required the use of a number of relatively new concepts, such as prosumption and other wikinomics models. In the article, we explain in detail, based on empirical and theoretical research, that digitization of public administration contributes to faster issuance of administrative decisions allowing for the commissioning of power plants based on renewable energy sources, and thus contributes to the decarbonization of the local economy. This is in line with the wisdom of wikinomics and the expectations of the inhabitants of the province. The prosumption model is the best form of operation for the renewable energy sector, which is confirmed by domestic and international experience. Along these lines, a coherent conceptual framework linking all the ideas under discussion has been developed.

\section{The Seven Wikinomics Business Models for Mass Collaboration}

Wikinomics is a new school of economic thinking that explains how mass and spontaneous collaboration of people supported by ICTs generates synergistic effects that contribute to the faster growth of markets and economies. In this aspect a growing role of open-source software is extremely important. At the heart of the wikinomics there are four principles of cooperation: openness, peering, sharing and acting globally. They break the traditional image of the behavior of business entities.

Traditionally, the notion of competitiveness is based on the fact that enterprises do not disclose their most valuable assets. However, such an approach prevents companies from using external sources of innovation and inventiveness which in turn, paradoxically, lowers their competitiveness. In this way openness becomes a necessity. Standardization is a powerful factor for openness, which is particularly important for information technology. These actions are supported by the open-source software movement. In addition, employees of open businesses have more confidence in the company and its associates, which reduces costs, improves innovation and strengthens loyalty.

Since the dawn of mankind, organizations of hierarchical structure have been the main driving force behind economic growth. Recently a new form of horizontal economic organization has emerged which competes with hierarchical organizations in the creation of products and information services. In this way a partnership is born, gradually blurring the differences between employers and employees, emphasizing the legitimacy and empowerment of employees and the role of teams.

A rigorous approach to intellectual property, so controlling it with patents, copyrights or trademarks, brings considerable profits to knowledge producers, but at the same time hinders societies access to basic tools for knowledge-based and wisdom-based businesses. However, it turns out that-according to the new intellectual property economy-the availability of resources by knowledge producers increases their potential for value creation. It is obvious that sharing resources does not necessarily mean sharing all of them. More and more often intellectual property is treated as an open-ended fund, some of the assets are protected and some are made available.

The new management approach postulated by wikinomics is based on the following seven co-operative patterns $[9,10]$ : 
1. Peer pioneers-people spontaneously creating innovative products that are often better than their business counterparts.

2. Ideagoras-new markets of ideas, innovations and people with exceptional qualifications that develop using the Internet outside of traditional ventures.

3. Prosumers-business entities which are not only consumers but active participants in the designing and manufacturing of new products, and are a non-standard source of innovation and creativity.

4. New Alexandrians-people who actively participate in multiplication, cumulation, systematization and rapid dissemination of knowledge to the whole world population.

5. Platforms for participation - products and technology infrastructure made available to the partner communities to create new values and initiate innovative undertakings.

6. Global plant floor-systems for designing and manufacturing goods or services based on global co-operation.

7. Wiki Workplace-a meritocracy that abolishes the hierarchy and connects the internal components of an enterprise to external social networks.

These strategies are the result of the rapid spread of ICT in the world economy, which are now considered to be top technologies. Two of them, prosumption and platforms for participation, are crucial in both the market sector and the public administration sector. They allow the introduction of the remaining five models. Therefore, in this paper they are the main subject of discussion.

The essence of prosumption is the blurring of differences between the classical producer and the consumer by integrating the latter one into the processes of designing, creating and producing goods and services [11-13]. According to the principles of wikinomics, the development of the prosumption processes-based on social networks-is inevitable, as it is the only way to unlock the potential for innovation and creativity of customers, and an effective way to reduce the costs of research and development in enterprises. However, this requires changing the traditional business model of the company and giving the prosumer communities some control over the product or service. However, de-prosumption may occur in some cases [14].

Technological basics of wikinomics are not without significance. A word wiki is defined as a type of website where the content is added and changed from a web browser, using a markup language, or by using the WYSIWYG (What You See Is What You Get) editor. The name of the wikinomics comes from the Hawaiian language, where the expression wiki wiki means very fast. Wiki-type websites are great for working on collaborative projects because they have the following features:

1. Speed and simplicity of creation and possibility of immediate updating,

2. Easiness to create links to internal and external resources,

3. Simplicity of formatting and inserting tags,

4. Opportunities for collaboration for many users, in which distance does not matter.

All this aims to make it easier for innovators to focus on substantive issues rather than wasting time on technical details.

This is how we come to the next business model of wikinomics-platforms for participation. In comparison with the traditional model, they allow businesses to operate on a wider stage, where many different partners can run their businesses and take part in improving existing solutions. In this way, the company's productive capacity can grow without additional fixed costs. An example of platform for participation in the market sector may be a website containing an e-commerce system for warehousing, purchasing, and distributing goods. They help create an on-the-fly-partnerships with the programmers' community, who add new values to existing ones. Companies providing their software services and databases through the application programming interface (API) create fluid webs of business partnerships. Such websites are called developer ecosystems. Platforms for participation have a decisive influence on the speed, range and increase of the chances of the innovation's success. 
The functioning of public administration is one of the basic factors determining the efficiency of the economic system in a given country. It is a manifestation of the political and economic power of the state and expresses its involvement in economic processes [15]. It also produces some feedback reactions that manifest themselves in a certain degree of citizens' confidence in the state.

The wikinomics business models are empirical and have been forced by the IT revolution. In the private sector, they are gradually becoming the standard, changing the image of the modern enterprise. Unfortunately, not all sectors of the economy are developing so dynamically. The most prominent example is public administration sector, which in many countries is fossilized and feebly susceptible to change [10]. On the other hand, harmonious economic development requires equal development of all sectors. If the public administration sector is left behind, it can easily become a barrier to innovation and entrepreneurship, which will block the development of the private sector.

Nowadays, in the era of very rapid ICT development, the public administration sector has faced the challenge of adapting it to the rapidly changing market sector. Traditional societies are inevitably transforming into information societies. Society expects the use of ICT in the provision of public administration services. This will reduce the cost of providing these services, improving their quality and reducing the complexity of administrative procedures. These phenomena were spotted by the United Nations and were the basis for a concept called e-Government [16].

The characteristic of prosumption in the public sphere is that it cannot be simply classified to the types of prosumption found in the literature concerning this issue. Among five such types distinguished by Dusi [17], prosumption in the public sphere fulfills the conditions for up to four of them: prosumer-government collaboration in service development, customer self-service, basic digital prosumption, and collaborative (peer-topeer) prosumption. In principle, only the bricolage in the literal sense is excluded.

\section{Prosumption in Polish Economy in the Pre-Information Era}

\subsection{Prosumption as the Most Important Component of Wikinomics}

In this section, we develop our previous research on prosumption processes in the Polish economy [18]. Out of all seven patterns of wikinomics, the utmost importance has prosumption, while others are conducive to its emergence and development. To shed some light on this economic category, Alvin Toffler proposes to extract two sectors in the economy [12] (pp. 283-285). Sector A provides free work done by people to meet their own needs, family's needs or local community's needs, whereas Sector B produces goods and services for sale or exchange's sake. In this context, the essence of the prosumption is the transfer of some business activities from the exchange sector to the manufacturing sector for own use. Mainstream economics focuses on Sector B, while Sector A is neglected. In this way, sector A becomes an invisible economy that is not included in the calculation of gross national product, although it is unimaginable that Sector B works properly without Sector A. The main cause of Sector A development in capitalist economy Toffler considers the Law of Relative Inefficiency [12] (pp. 289-290). According to this law the reduction of per-unit cost of goods can be achieved by the automation of their production which increases the relative cost of handcraft services. However, the aforementioned services are not prone to automation.

Considering the prosumption in Polish conditions it is essential to look at it in a historical perspective. It reveals new conditions of prosumption and proves that it depends mainly on the socio-economic system existing in the country. In the centrally planned economy, the prosumption did not consist, as in the market economy, on shifting production from Sector B to Sector A, but it was created from scratch. As a result, the development of Sector A required a slightly different materials management. Polish prosumers used mainly raw materials, which from the perspective of Sector B were post-production waste or scrap material. Therefore, creativity and knowledge are the components which are 
most important in the Sector A. It follows that prosumer experiences raised by the socialist economy can be easily adapted to the modern digital economy.

\subsection{The Examples of Prosumption Approaches in the Polish Economy}

A very good example of prosumption is the peasant windmills, which began to appear to a wide extent in the Podkarpacie region during the interwar period and the first years after the Second World War $[19,20]$. With such intensity, this phenomenon has not occurred anywhere else in the world. Within a few decades, almost two thousand small windmills were built. They were not service-oriented, they were mainly used to milling grain for a single household. However, this was a great advance, as previously hand-mills or hammer mills were used to such actions. The emergence of windmills was due to the specific peculiarity of economic conditions. At the turn of the nineteenth and twentieth centuries, the farms in the Podkarpacie region were small and had an excess of manpower. Meanwhile, at the end of the 19th century, the economic recovery was brought about by the construction of railway networks and oil mining. This allowed the inhabitants to obtain the necessary technical knowledge. At the same time remigrants from North America appeared in the region, and after 1918 soldiers who passed through many European countries during the First World War returned home. They, who have acquired the knowledge in the course of these escapades, became new Alexandrians and inspired the peer pioneers encountered on the spot, or even they themselves became such pioneers. So, we have here all elements of the current patterns of wikinomics.

Many examples of 1960s prosumption come from the Sądecczyzna region [21]. Sector A activity has taken the form of common in the socialist economy and now forgottencommunity actions that have proved to be an important and lasting factor in the region's economic development. In 1968, the small town of Grybów, now a part of Nowosądecki District, gained national fame by winning the title of Vice-Champion of thriftiness and the two million PLN prize. Today it would be 1,107,246.28 PLN or 243,945.95 EUR [22]. This success was mainly achieved through the involvement and work of the inhabitants, who within the framework of social activities, inspired by several local pioneers of partnership, have managed and rebuilt their city by their own forces. The value of these works at that time was valued at 1,170,000 PLN, which today equates to $647,739.07$ PLN or $142,708.38$ EUR [22]. In the same period a similar type of prosumption occurred in the village of Tegoborze, known from the rise of the famous prophecies concerning the future of Poland. The pioneer of the partnership was a businesswoman-Michalina Połomskawho performed numerous social functions there. She founded a dramatic group which showed Wiesław-Kazimierz Brodziński's idyll. The People's House was renovated for the income gained from the performances of the idyll. As part of the social activities valued at millions of PLN, the roads were built. The creativity and innovativeness of the inhabitants have been a source of investment in the apple orchards, allowing them to find a sponsor who renovated the Stadnicki Palace. Roszko's report shows that the prosumption social and voluntary contributions of the inhabitants to joint economic undertakings played an important role in the post-war development of the whole of the Sadecczyzna Region [21].

It is impossible not to mention here Adam Słodowy and the phenomenon of his TV series Do it yourself, which was broadcast from 1959 to 1983 [23]. He was a former lecturer in military higher education institutions where he constructed the projectile trajectory simulator. So, he was a perfect example of a pioneer of the partnership. His programs, teaching thousands of people the principles of prosumption, were an enormous success. Moreover, he wrote many do-it-yourself books, with a total circulation of 2.5 million copies [24]. You could learn from them how to make various items unavailable in the shortage economy system. These included toys, such as a washing machine for dolls' clothes, a free flying helicopter model or a piggy bank with a combination lock, and utility items, such as bookshelves, table lamps and bicycle trailers [25]. The two-way information flow was a platform for participation in mass media in the form of television and book 
publishing from peer pioneers to prosumers, as well as traditional mail from prosumers to peer pioneers.

\subsection{The Difference between Prosumption in a Centrally Planned Economy and Market Economy}

The power of prosumption in socialism and capitalism is not the same. These differences are easiest to explain on the example of car production. In the market economy, the share of Sector A was at most only a matter of fact that the car was assembled from the ready-made parts provided by Sector B [12] (pp. 294-295), but under socialism it was created from scratch on all available materials. At this point it is essential to recall Adam Słodowy, who has built a fully functional and safe car by himself. As he recalls this fact in the Motor Week Magazine, in 1946, he found an undamaged headlamp in a scrap yard, and within a few months he had built the rest of the vehicle by himself [26]. He described his experience in the book [27], which circulation of twenty thousand was sold immediately [28]. The enormous public interest in the possibility of constructing a car that was at that time practically unavailable, led to the Motor Weekly Magazine advertising a nationwide contest for Amateur Motor Cars (Samochody Amatorskie Motoru-in short SAMs in Polish) [29]. In this way, many successful SAMs designs were created [30].

After the Second World War, the interest of the Polish people in having their own car was so great that the then authorities had to quickly modify their economic plans. Bolesław Bierut, President of Poland from 1947 to 1952, published an album containing a six-year plan for the reconstruction of Warsaw in which he did not predict such a phenomenon [31]. In the book, there are monumental buildings, wide streets and futuristic cars, but the latter are not numerously represented. The authorities assumed that the people would be using primarily public transport. However, the Polish prosumers chose SAMs and the freedom associated with them. Already then the strength of the prosumption turned out to be so great that it changed completely the planned direction of economic development of the country. Figure 2 shows the differences between the processes of prosumption in a centrally planned economy and a market economy, based on the example of consumer involvement in car production. According to the mentioned illustration, many small hydropower plants operating until now were built in Poland in the years 1982-1989, so still under the socialist system [32]. The power of prosumption was greater in the socialist system with shortage economies; it manifested itself when unusable materials from previous production and other refuse found new uses. This signifies that the share of Sector A in centrally planned economies was greater than its share in comparable market economies.

An extreme example of the power of prosumption in the socialist economy is the construction of a stone bridge by Jan Stach, a farmer from Znamirowice village [33]. The bridge construction was dictated by necessity, as the unfriendly neighbor cut off the Stach's farm from the outside world. The only way was through the land of this neighbor, and he did not allow Stach to use it. As a result, the farmer decided to build a bridge himself from a sandstone called "Siwiec," which was the only available and free of charge material [34]. He had to go through a deep gorge (even $25 \mathrm{~m}$ depth) with steep cliffs on either side. At the bottom of this gorge there was a stream which flowed into Rożnowski Lake. The bridge was built in 1971, and its builder worked on it for four years. The construction is $13 \mathrm{~m}$ high, $20 \mathrm{~m}$ long and $7.5 \mathrm{~m}$ wide. In the middle of the construction there is a tunnel $3 \mathrm{~m}$ high with a barrel vault [35]. The stone for the construction was cut by the farmer from the nearby sandstone, and the pulling cows were used as a means of transport. They pulled the loaded wooden crate on the skids. Sand for the construction was extracted from the same rock that was crushed by a hand hammer. The only building material not produced by Stach was cement, which was difficult to acquire for the funds obtained from the sale of tomatoes and other agricultural crops. The bridge was built in accordance with all the rules of engineering art and even today a twenty ton lorry can drive through it. It is the world's largest stone bridge built by one man. Its current cost of construction is estimated at least 12 million PLN, equivalent to 2,643,812.38 EUR. 


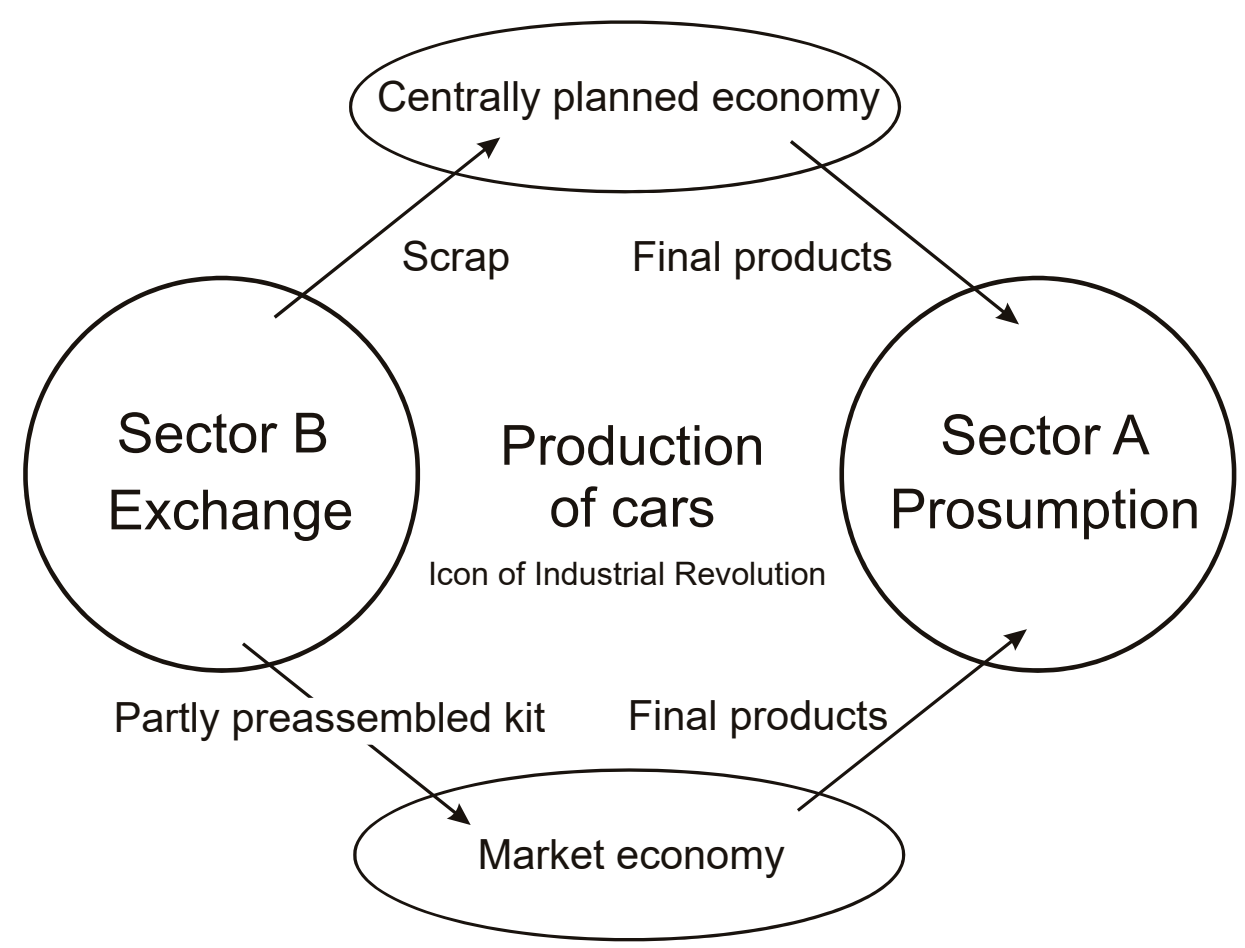

Figure 2. Car-building prosumption in a centrally planned economy and in market economy, and the relationship between Sectors A and B in both types of economies. Many micro and small hydropower plants were built in Poland in the years 1982-1989 in a prosumption system.

A documentary about Jan Stach and his work, Wznosze pomnik (I am Raising a Monument) was directed by Jerzy Jaraczewski [36]. Between 1972 and 1973 this documentary won three awards at film festivals in Poland (Cracow) and abroad: Germany (Oberhausen) and Australia (Melbourne). The national award is the Silver Lajkonik Award given for "high human, social and moral values, for a careful and clear form of film report".

In the 1960s and 1970s, the distinctive feature of Polish prosumption was the building, practically from scratch, of the different types of electrical and electronic equipment not available in Sector B. Taking such actions was encouraged by numerous and very popular handbooks, the most interesting of which appeared in many editions of Wojciechowski's work [37]. Based on this and other works, prosumers were able to construct such devices as a radio station, a photographic enlarger, a disco light controller, a transistor radio, or even a zero-generation computer, then called an electronic mathematical machine, which operated on electromagnetic relays.

\subsection{The Third Wave Economy}

The rapid development of Sector A in the modern world indicates the emergence of a new type economy, which, as Toffler points out [12] (pp. 292-293), is a lasting demarketization. Under these conditions, he claims, a new economy is needed, which he calls the Third Wave economy. Two previous waves were associated with agrarian revolution and industrial revolution. The essence of this economics should be a new concept of economy that takes into account Sector A and its relationship with Sector B. This will require redefining concepts such as labor efficiency, national income, welfare, poverty or unemployment. The dichotomous division of time in economics for work time and leisure time is also questionable [38]. Today, paid work in Sector B is put into opposition to free, voluntary and self-controlled work in Sector A.

For a long time prosumption has been an important element of the Polish economy. Presented in this paper historical cases of prosumption show that this is a permanent phenomenon. The associated with them partner communities have not only survived to 
this day, but they are still developing despite generational exchanges. In Polish society, the power of prosumption seems to be greater than elsewhere, which may give it a leading position in the new Third Wave economy.

\section{Prosumption as a Factor Enabling Poland to Achieve Climate Neutrality by 2050}

The power of prosumption in Poland in the pre-information era has not disappeared during the digital economy and continues to be an important factor in the economic development of the country, especially in the field of energy based on renewable sources development. According to the research hypothesis adopted in the study, it is currently the only economic force capable of ensuring Poland's achievement of climate neutrality by 2050. In addition, this goal should not be particularly difficult to reach in the Warmia and Mazury Province, as over 30\% of the region is covered by forests that naturally absorb carbon dioxide. If this province achieves climate neutrality by 2050, it will facilitate this goal to be attained in other regions in Poland. Currently, the province is an importer of electricity from coal-fired power plants hundreds of kilometers away, which means that it pays the highest energy rates in Poland. Energy prices are high due to heavy charges for transporting it over the electricity grids. In addition, these networks are often subject to breakdowns due to storms and wet snow, causing the inhabitants of some municipalities of Warmia and Mazury to experience the effects of interruptions in electricity supplies almost every day [39].

Prosumption is a valuable economic resource in every society. It manifests itself in spontaneous striving to improve economic processes owning to the natural creativity and ingenuity of people. The natural tendency of societies to innovate is a manifestation of this strength. As shown above, it allowed the achievement of many spectacular economic successes in the pre-information era. The peer pioneers are a source of original technical and economic knowledge that they share with the rest of society. In the digital economy, the power of prosumption is multiplied by making this knowledge digital, which makes it easier to collect, process and share. At the same time, it is global in nature and by means of computer networks it is available to interested stakeholders in every corner of the globe.

Currently, both in Warmia and Mazury and in other Polish regions, the conditions for the development of prosumption in the energy sector are extremely favorable. There is a surplus of workforce similarly to what could be observed in Podkarpacie in the past, and knowledge on obtaining electricity from renewable sources is widely available as a result of the progressive digitization of the economy. It is true that in some municipalities of the Warmia and Mazury Province, until recently there were difficulties in accessing the Internet. Nowadays a lot of progress has been made in this area. Unfortunately, in many districts of Warmia and Mazury, as well as in other regions of Poland, an unfavorable phenomenon is observed, consisting in shrinking of municipalities due to the outflow of population [40]. In recent years, many of the most enterprising people have left Warmia and Mazury in search of better living conditions in large Polish cities or in other European Union countries. The prosumption potential of many Polish regions is being lost in this way. This outflow should be stopped at all costs by creating appropriate living and working conditions in the country for the inhabitants and directing their economic activity towards obtaining electricity from renewable sources. It is necessary to benefit from the fact that the propensity for prosumption is permanent and can be passed down from generation to generation, which often results in the formation of family businesses operating in the renewable energy sector [41].

The development of the prosumer model in the Polish energy sector is conditioned today to a lesser extent by the Law of Relative Inefficiency, which was described by Toffler, but the application of the model is forced by objective factors in the form of the progressing process of global warming and international obligations in terms of decarbonization of national economies adopted almost by all the countries of the world. The problem can be considered from a different perspective with the assumption that the law still works, but the reason for this is no longer the dizzying increase in the prices of craft services, but the 
dizzying cost of maintaining human life and health in conditions of the growth of global warming and environmental degradation.

Prosumption experience of Polish society in the use of renewable energy sources, mainly wind and water, can be traced many years back. This phenomenon is well illustrated in Figure 2, as all possible materials were used to build windmills and watermills or even passenger cars. Parts coming from broken and no longer usable drilling machines and trucks found new usage, for example, the differential gears (differentials). After the Second World War, these were parts from crashed tanks, military armored vehicles and selfpropelled guns $[19,20]$. Nowadays, the use of prosumption experiences from the previous economic system is a necessity, because the game is at a much higher stake incomparable to anything that was before. The prize may be the survival of humanity.

Today, the society in Warmia and Mazury is ready to adopt a prosumption model in the use of renewable energy sources. However, administrative barriers remain and no economic incentive system has been established for clean energy producers. The situation is gradually improving owning to the digitization of the public administration sector, but progress in this area is still slow. Full decarbonization of the Polish economy is likely to be forced by prosumers, as shifting towards renewable energy sources and the related diversification of electricity production will give households and enterprises greater economic freedom in the form of energy independence. The situation is similar to the one observed in the period after 1945, when prosumers reached for freedom of free movement and began to build cars themselves. Just as the Polish government once had to adjust its economic plans regarding transport methods and focus on the development of the car industry under social pressure, now it will be forced under the pressure of prosumers to commit to achieving climate neutrality by 2050 . Otherwise, access to the Just Transition Fund will be halved and for Poland this could mean a loss of up to 5 billion EUR [42].

\section{6. "If They Wanted to Understand ... ": Cooperation of the Society of Warmia and Mazury with Public Administration in the Digital Sphere}

The ability of the municipal public administration sector in Warmia and Mazury to use the prosumption potential of the society in this region will be examined in this part of the article. Two approaches were used in the study. Correspondence analysis was used to assess the degree of preparation of the society of Warmia and Mazury Province to perform the role of prosumers in the public administration sector. Moreover, the possibilities of transforming the websites of municipal public administration offices into platforms for participation were evaluated with use of the binary method.

\subsection{The Research Hypotheses}

The introduction of wikinomics business models into the public administration sector requires the dissemination of knowledge regarding digital prosumption in society and an appropriate level of development of information technologies that would allow the transformation of already existing websites of municipal offices into platforms for participation. Simultaneous fulfillment of these postulates is a sufficient condition to implement the other wikinomics models.

Research questions raised before the start of the analysis focus on whether economic entities from the Warmia and Mazury Province are prepared to undertake tasks related to digital prosumption and whether websites of municipal public administration offices can act as platforms for participation. Therefore, two research hypotheses have been adopted:

1. The society considers the prosumption principles arising from business models of wikinomics as critical for economic growth and development of the Warmia and Mazury Province;

2. Currently, the websites of municipal offices are not able to act as platforms for participation enabling digital prosumption and implementation of other models of wikinomics. This is a source of significant development asymmetry between the public 
administration sector and the market sector, which works to the detriment of both sectors.

Two test methods will be used to verify these hypotheses. The readiness of the society of Warmia and Mazury to perform the role of digital prosumers will be assessed on the basis of calculations made as part of correspondence analysis, while the $k$-means clustering method will be used to determine the affluence of the websites of municipal public administration offices.

\subsection{The Prosumption in Public Administration Sector}

\subsubsection{The Principles of Prosumption}

In 2015, a direct survey was conducted in Warmia and Mazury Province (northeastern Poland), which aimed to become acquainted with the opinions of clients on the implementation of the ten principles of prosumption proposed by the authors in the public administration sphere [43]. Respondents can be divided into three groups: Polish citizens, employees and entrepreneurs. This includes three types of relationships: G2C (government to citizens), G2E (government to employees), and G2B (government to businesses). Table 1 presents prosumption rules based on the business models of wikinomics [43].

Table 1. The principles of prosumption.

\begin{tabular}{cl}
\hline Codes & \multicolumn{1}{c}{ Ten Principles of Prosumption } \\
\hline P.1 & An official's efficiency of service \\
P. 2 & Expertise and competence of an official \\
P.3 & The personal culture of an official \\
P. 4 & Technical conditions for providing of services \\
P.5 & Availability of information, i.e., knowledge of where and how to deal with the \\
P.6 & matter \\
P.7 & Honsistent communication in the client-official relationship \\
P. & A more favored attitude of the officials \\
P.9 & Possibility of dealing with the matters at one branch of the office \\
P.10 & The ability to deal with the matters online \\
\hline
\end{tabular}

The most universal statistical formula, used to establish the minimum sample size $N_{\min }$ of the questionnaire survey, has the following form:

$$
N_{\text {min }} \geq \frac{\left(Z_{\alpha / 2}\right)^{2}}{4 E^{2}},
$$

where $Z_{\alpha / 2}$ is the number determined by the desired level of confidence, and $E$ stands for the margin of error. Prior to the research, it was assumed that the confidence level is $95 \%$, which gives $\alpha=1-0.95=0.05$, and thus $\alpha / 2=0.025$. Then $1-(\alpha / 2)=0.975$. Afterwards, based on the standard normal distribution table, we obtain $Z_{0.025}=1.96$. The applied margin of error is the commonly used value $E=0.03$. After substituting these numbers for the inequality (1), $N_{\text {min }} \geq 1067$ is obtained. In total, 1821 reliable surveys were collected, which implies meeting the condition of the minimum sample size.

During participation in the research, respondents selected at least one principle of prosumption that they considered important. As a result, a contingency table was created containing the most important number of statistical features describing the prosumption in the public administration sphere (Table 2). The sex and age of respondents were taken into account, within the latter variable, five age groups for women and five age groups for men were identified. Table 2 is the starting point for the correspondence analysis [43]. 
Table 2. Number of statistical features describing the prosumption according to sex and age groups of respondents.

\begin{tabular}{|c|c|c|c|c|c|c|c|c|c|c|c|}
\hline \multirow{2}{*}{$\begin{array}{l}\text { Age } \\
\text { Groups }\end{array}$} & \multirow{2}{*}{$\begin{array}{c}\text { Sex: } \\
\text { W-Women; } \\
\text { M-Men }\end{array}$} & \multicolumn{10}{|c|}{$\begin{array}{l}\text { Number of Ratings Characterizing Individual Principles of Prosumption in Public Administration } \\
\text { in the Warmia and Mazury Province }\end{array}$} \\
\hline & & P.1 & P. 2 & P.3 & P.4 & P.5 & P.6 & P.7 & P.8 & P.9 & P.10 \\
\hline $18-20$ & W1 & 49 & 50 & 24 & 8 & 28 & 13 & 58 & 18 & 29 & 8 \\
\hline $21-35$ & W2 & 351 & 352 & 180 & 63 & 182 & 252 & 327 & 169 & 163 & 203 \\
\hline $36-45$ & W3 & 44 & 45 & 21 & 16 & 20 & 35 & 63 & 9 & 27 & 47 \\
\hline $46-60$ & W4 & 44 & 66 & 15 & 5 & 21 & 42 & 39 & 11 & 12 & 35 \\
\hline Up 60 & W5 & 19 & 25 & 9 & 9 & 11 & 13 & 20 & 12 & 13 & 17 \\
\hline $18-20$ & M1 & 58 & 72 & 40 & 28 & 38 & 58 & 62 & 31 & 34 & 25 \\
\hline $21-35$ & M2 & 343 & 399 & 242 & 99 & 240 & 225 & 416 & 228 & 249 & 304 \\
\hline $36-45$ & M3 & 68 & 75 & 32 & 20 & 32 & 11 & 67 & 33 & 23 & 41 \\
\hline $46-60$ & M4 & 32 & 49 & 28 & 13 & 52 & 24 & 46 & 41 & 25 & 31 \\
\hline Up 60 & M5 & 12 & 17 & 8 & 7 & 11 & 7 & 17 & 6 & 8 & 9 \\
\hline
\end{tabular}

\subsubsection{The Correspondence Analysis}

The correspondence analysis belongs to multidimensional statistical methods consisting in investigating the coexistence of phenomena. Its purpose is to recreate the distances between points representing columns or rows of the two-way and multi-way tables in the space with fewer dimensions. This is done in such a way as to keep as much information as possible about the differentiation of rows and columns [44-47]. These tables contain some measures that characterize the relationships between rows and columns. As a result of usage of this method we obtain graphical information about the structure of relationships of the categorical variables contained in the tables. In the course of the study, the directions of the subsequent axes (dimensions) are determined so that subsequent dimensions explain an ever-smaller part of the overall value of chi-squared statistics (or inertia). The number of dimensions is determined by the cumulative percentages of inertia explained by the dimension of the space taken. In the applied method, the singular-value decomposition of the correspondence matrix according to singular values has a basic meaning $[48,49]$.

In correspondence analysis, inertia is equivalent to the notion of variance often found in statistics. Total inertia is a measure of the dispersion of row profiles or column profiles around their average profiles. The first step in this method involves converting a multi-way table into a correspondence matrix, which involves replacing entries at relative frequencies. The entries in a multivariate table are simply divisible by their grand total. Next, the row profile matrix and the column profile matrix are determined. The matrix of row profiles is determined by dividing the relative frequencies in each row of the correspondence matrix by the sum of all frequencies in the corresponding row. Similarly, the matrix of the column profiles is calculated by dividing each relative frequency in the column of the correspondence matrix by the sum of the frequencies in the corresponding column. The average row profile is equal to the sum of all relative frequencies in the correspondence matrix columns, and the average column profile is the sum of all relative frequencies in the correspondence matrix rows.

The correspondence analysis also includes the notion of mass [50]. The mass of the row is derived by summing the relative frequencies in a given row, while the mass of the column is calculated by summing the relative frequencies in a given column. The mass of the row or column indicates the validity of this row or column in the conducted study. While the relative frequencies show how one unit of mass is distributed across the cells. In the correspondence analysis the distances between row profiles or column profiles are calculated using the chi-square metric.

Correspondence analysis is increasingly used in economic research, although its potential has not yet been fully appreciated by economists. It examines the co-occurrence of economic variables that can be put on the nominal scale in Steven's classification system. This scale is only used to classify or categorize the values of the variables, any one-toone substitution of the assigned numbers is possible, and the only empirical operation 
is the determination of equality [51,52]. Correspondence analysis can be used in public administration to explain the perception gaps, which are the differences between the service expected and service perceived by customers. It can be shown that these gaps are the result of systematic errors in communication between municipal offices and citizens, which would require rejecting the hypothesis of rational expectations and adopting the hypothesis of adaptive expectations [53]. Inclusion of prosumption in the considerations allows us to prove the claim that it is a source of rationality in public administration [43]. Other applications of correspondence analysis focus on the study of the innovativeness of industrial processing companies in changing economic conditions. The most interesting findings in this respect include the demonstration that [54-57]:

(1) such features as ownership or size of enterprises should be analyzed simultaneously;

(2) the Red Queen effect can be observed in the manufacturing sector when the most innovative enterprises exert pressure on all other companies to keep investing in innovations to avoid lagging behind the leader;

(3) the manufacturing industry is more sensitive to secular trends than business fluctuations;

(4) the innovation of enterprises is slowly increasing regardless of the phases of the business cycle;

(5) the global financial crisis was a turning point between two Kondratieff waves;

(6) public enterprises are less innovative in comparison to enterprises from other ownership sectors.

This statistical method also enabled for the evaluation of the cross-border cooperation between Poland and Russia [58]. All these studies are directly or indirectly related to the use of renewable energy sources by enterprises, as this type of activity is slowly becoming a new measure of their innovation.

\subsubsection{Calculations}

Table 3 shows the quantitative characteristics of the matrix created by the empirical data contained in the contingency table (Table 2). It follows that three dimensions allow the reproduction of $72.5859 \%$ of inertia, that is, the total value of chi-square statistic. Values relevant for further calculations are shown in Table 3. When you select three dimensions, it is essential to calculate the coordinates of the row profiles and column profiles in the orthogonal principal axes. Tables 4 and 5 show the results of the calculations made in the correspondence analysis. Table 4 contains the coordinates of the rows (age groups with sex division) whereas Table 5 contains the coordinates of the columns (ratings of particular principles of prosumption by the clients of the offices). Moreover, Tables 4 and 5 contain values describing the quality of the solution. This information is necessary to draw up correspondence analysis plots and to show the co-occurrence between the perception of the principles of prosumption by the clients and their sex and age division [59-61].

Table 3. Correspondence matrix characteristics for data in Table 2.

Eigenvalues and Inertia for All Dimensions. Input Table (Row $\times$ Column): $10 \times 10$. Total Inertia $=0.03260$, chi-square $\left(\chi^{2}\right)=238.86, d f=81, p=0.0000$

\begin{tabular}{cccccc}
\multirow{2}{*}{$\begin{array}{c}\text { Number of } \\
\text { Dimensions }\end{array}$} & \multicolumn{4}{c}{ Total Inertia $=0.03260$, chi-square $\left(\chi^{2}\right)=238.86, d f=81, p=0.0000$} \\
\cline { 2 - 6 } & Singular Values & Eigenvalue & Percent of Inertia & $\begin{array}{c}\text { Cumulated } \\
\text { Percent of Inertia }\end{array}$ & $\begin{array}{c}\text { Chi-Square } \\
\text { Distance }\left(\chi^{2}\right)\end{array}$ \\
\hline 1 & 0.107743 & 0.011609 & 35.61420 & 35.6142 & 85.06800 \\
2 & 0.078466 & 0.006157 & 18.88896 & 54.5032 & 45.11813 \\
3 & 0.076773 & 0.005894 & 18.08276 & 72.5859 & 43.19244 \\
4 & 0.061355 & 0.003764 & 11.54886 & 84.1348 & 27.58559 \\
5 & 0.054511 & 0.002971 & 9.11615 & 93.2509 & 21.77482 \\
6 & 0.038032 & 0.001446 & 4.43743 & 97.6883 & 10.59923 \\
7 & 0.023385 & 0.000547 & 1.67765 & 99.3660 & 4.00724 \\
8 & 0.013974 & 0.000195 & 0.59910 & 99.9651 & 1.43100 \\
9 & 0.003373 & 0.000011 & 0.03490 & 100.0000 & 0.08336 \\
\hline
\end{tabular}


Table 4. Row coordinates and the statistics of the quality of the solution.

\begin{tabular}{|c|c|c|c|c|c|c|c|c|c|c|c|c|c|}
\hline \multirow{3}{*}{$\begin{array}{l}\text { Name of } \\
\text { Rows }\end{array}$} & \multicolumn{13}{|c|}{ Rows Coordinates and Contributions to Inertia. Input Table $($ Row $\times$ Column): $10 \times 10$. Standardization: Row and Column Profiles } \\
\hline & \multirow{2}{*}{$\begin{array}{c}\text { Row } \\
\text { Number }\end{array}$} & \multirow[b]{2}{*}{ Mass } & \multirow[b]{2}{*}{ Quality } & \multirow{2}{*}{$\begin{array}{l}\text { Relative } \\
\text { Inertia }\end{array}$} & \multicolumn{3}{|c|}{ Coordinates } & \multicolumn{2}{|c|}{ Dimension 1} & \multicolumn{2}{|c|}{ Dimension 2} & \multicolumn{2}{|c|}{ Dimension 3} \\
\hline & & & & & $\begin{array}{c}\text { Dimension } \\
1\end{array}$ & $\begin{array}{c}\text { Dimension } \\
2\end{array}$ & $\begin{array}{c}\text { Dimension } \\
3\end{array}$ & Inertia & $\operatorname{Cos}^{2}$ & Inertia & $\operatorname{Cos}^{2}$ & Inertia & $\operatorname{Cos}^{2}$ \\
\hline W1 & 1 & 0.038892 & 0.843639 & 0.135239 & 0.108459 & 0.281588 & -0.067575 & 0.039411 & 0.103785 & 0.500868 & 0.699566 & 0.030131 & 0.040288 \\
\hline W2 & 2 & 0.305950 & 0.811946 & 0.094870 & -0.075806 & 0.028699 & 0.040453 & 0.151452 & 0.568550 & 0.040927 & 0.081486 & 0.084945 & 0.161910 \\
\hline W3 & 3 & 0.044623 & 0.805353 & 0.113822 & -0.128450 & -0.122714 & -0.188151 & 0.063423 & 0.198447 & 0.109140 & 0.181120 & 0.268012 & 0.425787 \\
\hline W4 & 4 & 0.039574 & 0.756535 & 0.158284 & -0.313948 & -0.001526 & -0.008069 & 0.336005 & 0.756017 & 0.000015 & 0.000018 & 0.000437 & 0.000499 \\
\hline M1 & 6 & 0.060862 & 0.333501 & 0.103142 & -0.058793 & 0.055340 & 0.109101 & 0.018123 & 0.062577 & 0.030273 & 0.055441 & 0.122909 & 0.215483 \\
\hline M2 & 7 & 0.374591 & 0.874865 & 0.090489 & 0.060778 & -0.055221 & -0.012058 & 0.119200 & 0.469137 & 0.185522 & 0.387263 & 0.009240 & 0.018465 \\
\hline M3 & 8 & 0.054858 & 0.701186 & 0.120885 & 0.105863 & 0.109012 & -0.165147 & 0.052960 & 0.156027 & 0.105882 & 0.165447 & 0.253841 & 0.379712 \\
\hline M4 & 9 & 0.046534 & 0.811846 & 0.142648 & 0.228538 & -0.041168 & 0.164911 & 0.209366 & 0.522713 & 0.012809 & 0.016961 & 0.214706 & 0.272171 \\
\hline M5 & 10 & 0.013919 & 0.244328 & 0.021354 & 0.090470 & 0.024372 & -0.058644 & 0.009814 & 0.163676 & 0.001343 & 0.011878 & 0.008122 & 0.068774 \\
\hline
\end{tabular}

Table 5. Column coordinates and the statistics of the quality of the solution.

\begin{tabular}{|c|c|c|c|c|c|c|c|c|c|c|c|c|c|}
\hline \multirow{3}{*}{$\begin{array}{l}\text { Name of } \\
\text { Columns }\end{array}$} & \multicolumn{13}{|c|}{ Column Coordinates and Contributions to Inertia. Input Table (Row $\times$ Column): $10 \times 10$. Standardization: Row and Column Profiles } \\
\hline & \multirow{2}{*}{$\begin{array}{l}\text { Column } \\
\text { Number }\end{array}$} & \multirow[b]{2}{*}{ Mass } & \multirow[b]{2}{*}{ Quality } & \multirow{2}{*}{$\begin{array}{l}\text { Relative } \\
\text { Inertia }\end{array}$} & \multicolumn{3}{|c|}{ Coordinates } & \multicolumn{2}{|c|}{ Dimension 1} & \multicolumn{2}{|c|}{ Dimension 2} & \multicolumn{2}{|c|}{ Dimension 3} \\
\hline & & & & & $\begin{array}{c}\text { Dimension } \\
1\end{array}$ & $\begin{array}{c}\text { Dimension } \\
2\end{array}$ & $\begin{array}{c}\text { Dimension } \\
3\end{array}$ & Inertia & $\operatorname{Cos}^{2}$ & Inertia & $\operatorname{Cos}^{2}$ & Inertia & $\operatorname{Cos}^{2}$ \\
\hline P.1 & 1 & 0.139192 & 0.817588 & 0.082854 & -0.068227 & 0.098145 & -0.039695 & 0.055815 & 0.239917 & 0.217765 & 0.496461 & 0.037210 & 0.081211 \\
\hline P.2 & 2 & 0.156932 & 0.508806 & 0.066374 & -0.054641 & 0.060903 & -0.017878 & 0.040361 & 0.216566 & 0.094543 & 0.269056 & 0.008510 & 0.023185 \\
\hline P.3 & 3 & 0.081741 & 0.504630 & 0.029566 & 0.070122 & 0.002839 & 0.032005 & 0.034624 & 0.417064 & 0.000107 & 0.000684 & 0.014206 & 0.086882 \\
\hline P. 4 & 4 & 0.036572 & 0.135478 & 0.104089 & 0.092347 & -0.027742 & -0.057192 & 0.026867 & 0.091924 & 0.004572 & 0.008296 & 0.020296 & 0.035258 \\
\hline P.6 & 6 & 0.092795 & 0.965358 & 0.236583 & -0.241205 & -0.058567 & 0.136434 & 0.465068 & 0.700093 & 0.051697 & 0.041275 & 0.293052 & 0.223989 \\
\hline P.7 & 7 & 0.152156 & 0.687911 & 0.049427 & 0.018198 & 0.033604 & -0.076312 & 0.004341 & 0.031277 & 0.027906 & 0.106646 & 0.150331 & 0.549988 \\
\hline P.8 & 8 & 0.076146 & 0.836821 & 0.115906 & 0.168257 & -0.017893 & 0.113527 & 0.185701 & 0.570600 & 0.003960 & 0.006453 & 0.166505 & 0.259767 \\
\hline P.9 & 9 & 0.079558 & 0.356333 & 0.065360 & 0.090985 & -0.032972 & -0.013292 & 0.056734 & 0.309137 & 0.014048 & 0.040598 & 0.002385 & 0.006598 \\
\hline P.10 & 10 & 0.098253 & 0.906103 & 0.155830 & -0.027041 & -0.191390 & -0.097371 & 0.006189 & 0.014144 & 0.584546 & 0.708561 & 0.158045 & 0.183398 \\
\hline
\end{tabular}


Row and column profile standardization were used in the calculations in Tables 4 and 5, which means that simultaneous analysis of the points representing the row profiles, and the column profiles will be used for the graphical interpretation of the results. This allows us to investigate the co-occurrence of points representing age groups with the sex division and points responsible for each principle of prosumption. Regarding the masses of rows or columns, they provide information about their rank and importance. In Table 4, the largest masses have rows 7 (0.374591) and 2 (0.305950), which corresponds to the groups M2 and W2. This means that these respondents are the most frequent clients of municipal public administration offices and their opinion should be taken into account in the first place. This is understandable because young people of both sexes aged between 21 and 35 years old are at the beginning of their life and career path.

In both Tables 4 and 5, the quality of the individual points is also shown. The quality of a point should be understood as the quotient of the square of the distance from the origin of the assumed coordinate system and the square of the distance from the center of the system with the greatest number of dimensions to be tested. Distances are determined by the chi-square metric. According to Table 3, the maximum number of dimensions of the issue discussed here is nine. This is the smaller of the following two numbers: the number of rows minus one or the number of columns minus one. So, the calculation of the number of dimensions is simple: $10-1=9$. The quality of a point takes values from 0 to 1 . It informs you about the quality of the representation of individual rows or columns in the space with fewer dimensions. In the discussed issue this will be either a three-dimensional space (Figure 3) or a two-dimensional space (Figures 4-6). The higher the quality of a point, the better it is represented on the graph. In Table 4, rows 7 (M2-0.874865) and 1 (W1-0.843639) have the best quality. Whereas in Table 5, columns $6(0.965358)$ and 10 (0.906103) have the highest values, which means that P.6 and P.10 are the best represented principles of prosumption. In this way it was proven that the implementation of the principles of prosumption would not be possible without first transforming the websites of the municipal offices into the platforms for participation. The relative inertia of a point determines its contribution to overall inertia. It follows from Table 4 that the greatest contribution to inertia among the rows have points W4 (0.158284) and M4 (0.142648), whereas from Table 5 that the greatest contribution to inertia among the columns have points P.6 (0.236583) and P.10 (0.155830). There is a difference between the quality of the point and its relative inertia. The quality of a point determines its contribution to total inertia at a given space dimension, while the relative inertia determines the proportion of the point in total inertia in the original nine-dimensional space. 


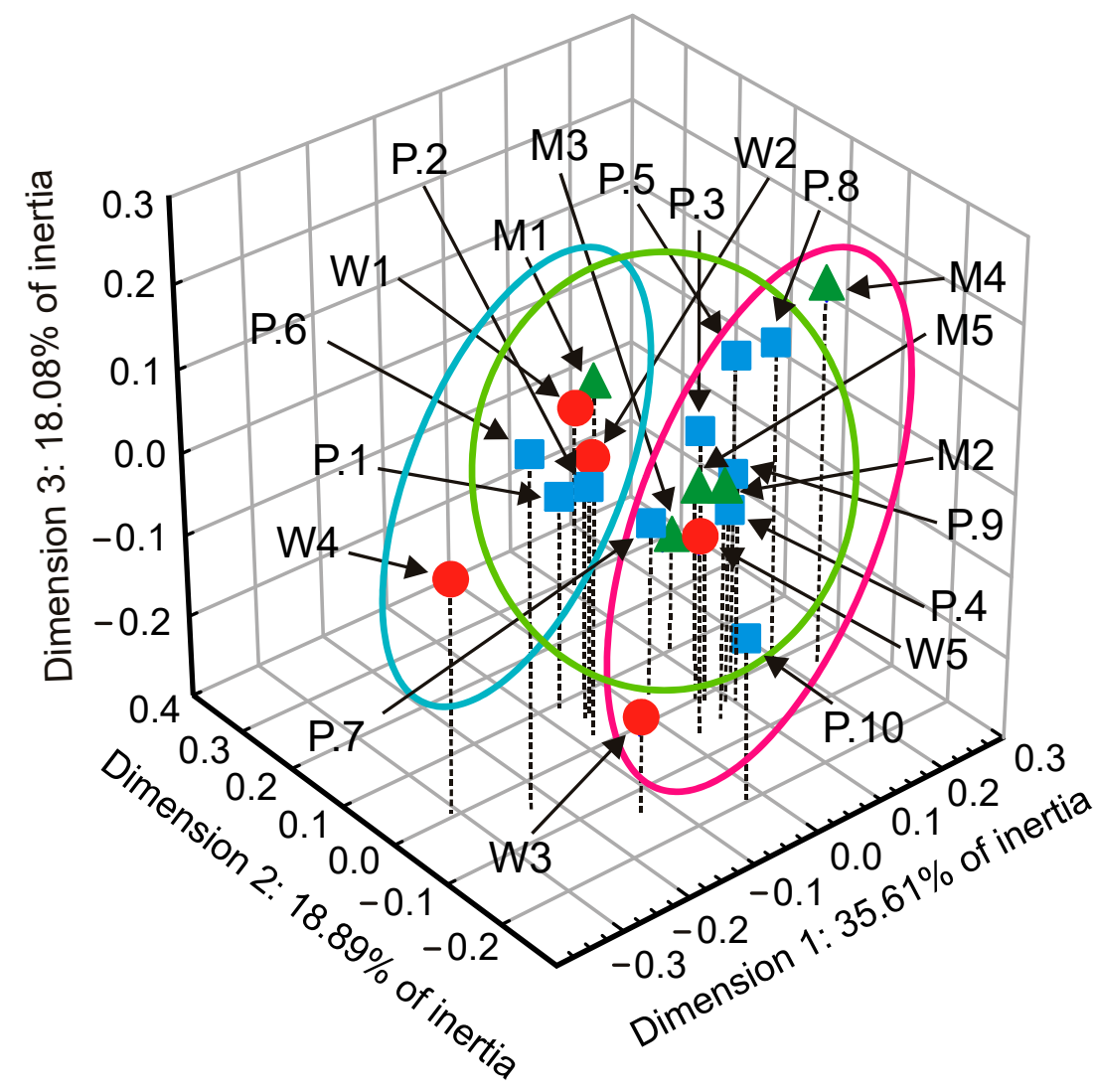

Figure 3. 3D plot of column and row coordinates: dimension $1 \times 2 \times 3$. Input table (rows $\times$ columns): $10 \times 10$.

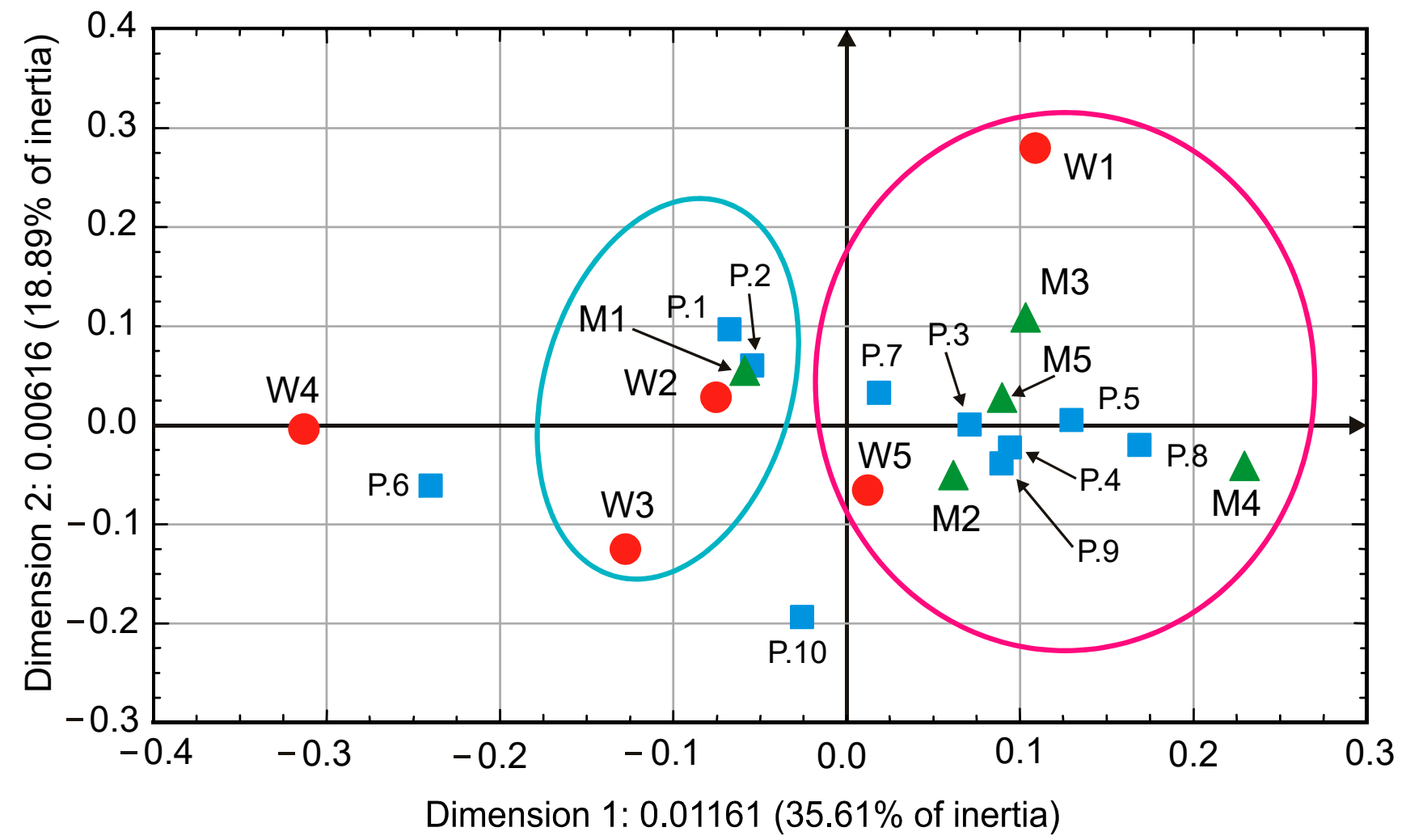

Figure 4. Two dimensional plot of column and row coordinates: dimension $1 \times 2$. Input table (rows $\times$ columns): $10 \times 10$. 


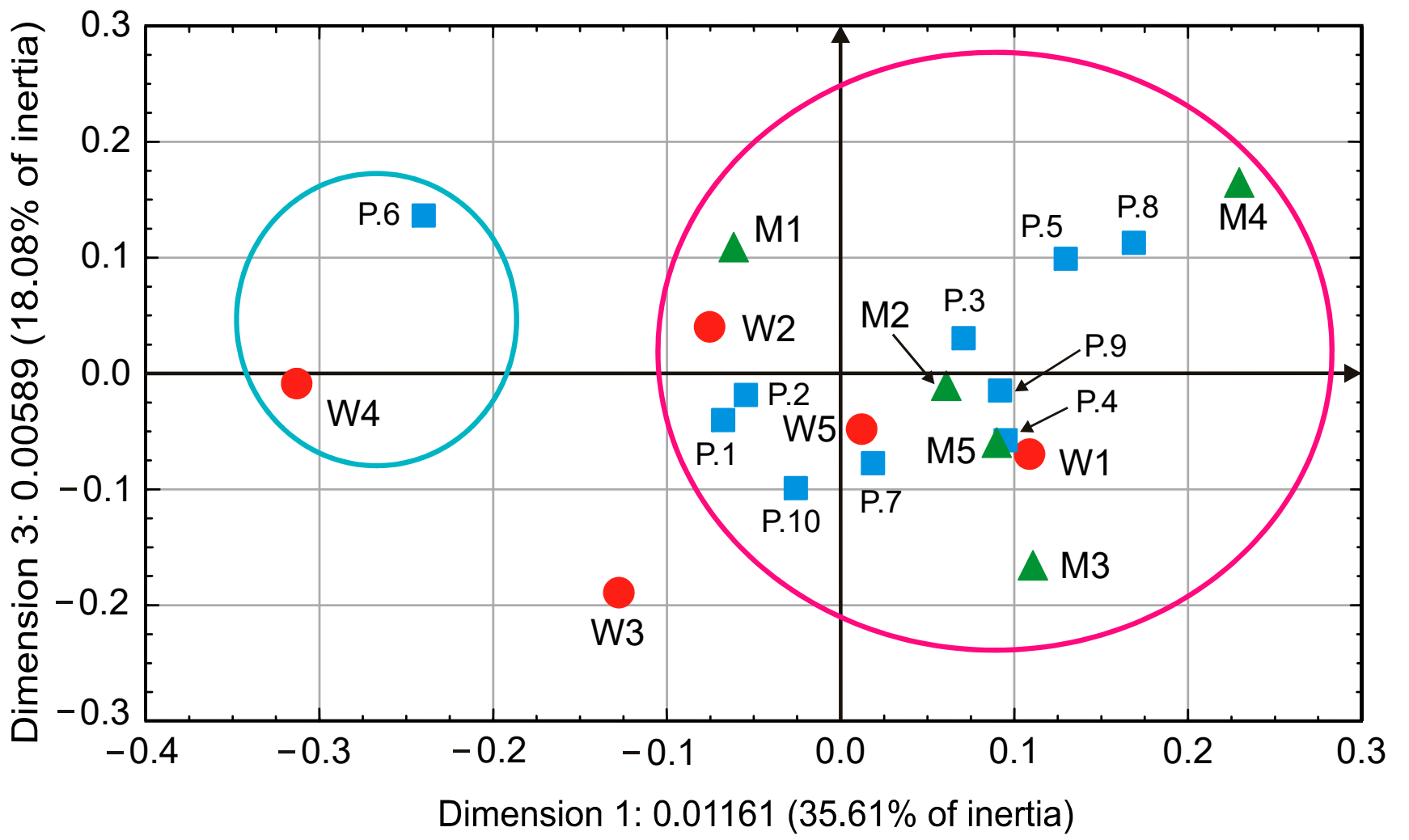

Figure 5. Two dimensional plot of column and row coordinates: dimension $1 \times 3$. Input table (rows $\times$ columns) $10 \times 10$.

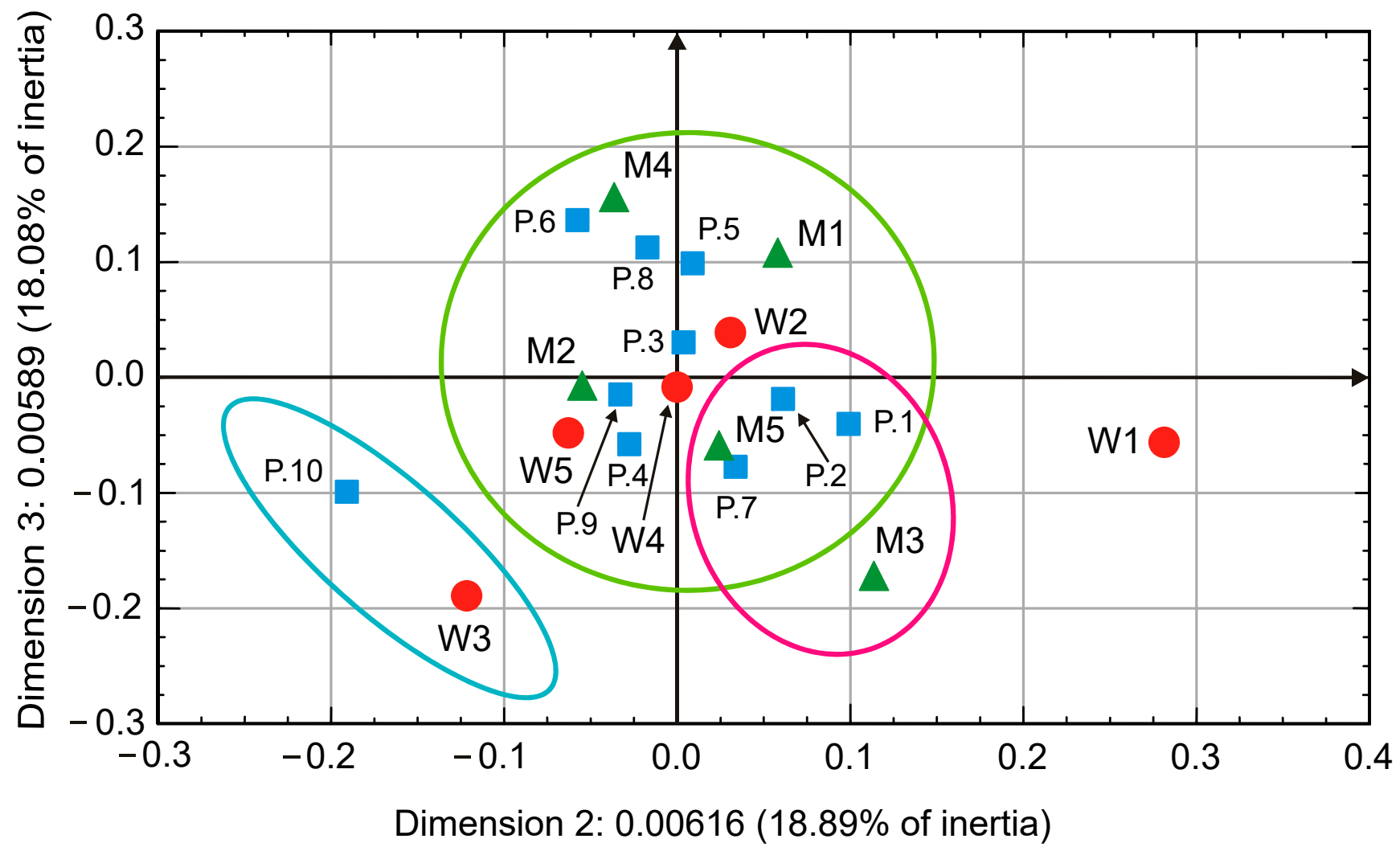

Figure 6. Two dimensional plot of column and row coordinates: dimension $2 \times 3$. Input table (rows $\times$ columns): $10 \times 10$.

Tables 4 and 5 also show the distribution of overall inertia on individual dimensions (axes). Points that have a greater share of inertia have largely contributed to the definition 
of dimension. The first dimension was most influenced by the W4 (0.336005) and M4 (0.209366) groups, as well as the P.6 (0.465068) and P.8 (0.185701) principles. On the other hand, squares of cosine represent the quality distribution of a given point on particular dimensions. If for a given row we sum all the values of the squares of cosine, we will get a measure of quality. These values are therefore the contribution of the dimension in the point inertia. This share is the square of the cosine of the angle between the segment connecting the average profile to the point discussed and the main axis. From Tables 4 and 5 follows that the first dimension well describes (the largest value of the square of the cosine) the points representing W4 (0.756017) and W2 (0.568550), as well as the principles P.6 (0.700093) and P.8 (0.570600).

\subsubsection{Results}

Figure 3 can be interpreted in accordance with the three marked ellipses for three different but mutually complementary ways. Red circles represent age groups of women, green triangles symbolize age groups of men, whereas blue squares denote prosumption principles. The first cluster is in the middle, while the other two are located to the right and left of the graph. The cluster marked by the ellipse in the middle indicates that all the principles of prosumption are approved by most of the respondents. Only two age groups of women-W3 and W4, as well as one age group of men-M4, were outside the marked area. The right ellipse includes seven principles of prosumption-P.3-P.5, P.7-P.10, one age group of women-W5, and three age groups of men-M2, M3 and M5, so these variables tend to co-occur. On the other hand, on the basis of the left cluster we can conclude that the three principles of prosumption-P.1, P.2 and P.6 are preferred by three age groups of women-W1, W2, W4, and one age group of men-M1.

Because of the perspective phenomenon, the conclusions of the three-dimensional cluster of points (Figure 3) should be verified on two-dimensional sections. The twodimensional section shown in Figure 4 confirms most of the previous conclusions. In the right part of the chart, the six principles of prosumption-P.3-P.5 and P.7-P.9 are focused around two age groups of women-W1 and W5, and four age groups of men-M2 to M5, indicating the specific preferences of these respondents. On the left side we have the co-occurrence of the principles P.1 and P.2 with two age groups of women-W2 and W3, and one age group of men-M1. The further left points, W4 and P.6, are relatively isolated, but their location may also indicate that women in W4 prefer the principle P.6.

Figure 5 illustrates further investigation. The right ellipse contains almost all the principles of prosumption (except P.6), three age groups for women-W1, W2 and W5, and all age groups for men. This means that the need to radically change the functioning of public administration sphere is underlined by the majority of respondents. The conclusion of Figure 4 is also confirmed that principle P.6 is most emphasized by women of age group W4. Whereas point W3 seems relatively isolated.

The conclusions provided in Figure 6 are very similar to those that have the threedimensional cross-section shown in Figure 3. The central ellipse contains almost all the principles of prosumption (except P.10), three age groups of women-W2, W4 and W5, and four groups of men-M1, M2, M4 and M5. The relatively close proximity of these points proves that (and this is the reflection of the views of the majority of respondents) there is an urgent need to introduce prosumption into the public administration sector. Near the central ellipse there is a point representing the age group of men-M3. The closest to it are the three principles of prosumption-P.1, P.2 and P.7. This proves that this group of respondents puts particular emphasis on the efficiency of the service process, the professionalism, and the competence of officials. A subgroup of points marked with a smaller ellipse also contains points M5, so the same principles are also close to men over 60. In this cross-section, the point W1 is relatively isolated. The third ellipse consists of only two points, W3 and P.10, so women aged 36 to 45 are the most innovative group among respondents, as they strongly emphasize the importance of a complementary wikinomics model-platforms for participation. 


\subsection{Websites of the Public Administration Offices as Platforms for Participation}

This part of the research was based on previously obtained results [43,53]. A wellprepared internet service of the municipal administration office enables the presentation and promotion of municipality. It allows us to attract investors who are able to provide workplaces for the local community and also provide an influx of tourists. In addition, it provides the opportunity to disseminate up-to-date information on the life of the inhabitants of the municipality.

The implementation of prosumption in the public administration sphere will not be possible without teleinformatics, which means the need to transform the public administration offices websites into modern platforms for participation. In this process, the starting point is the evaluation of the existing municipal offices websites, taking into account the recommendations of wikinomics. Such an evaluation was made in Poland in 2015. The research covered all municipal offices in the Warmia and Mazury Province. The authors have proposed ten criteria for the functionality of websites, the fulfillment of which means that the websites can serve as platforms for participation. These criteria are as follows:

1. Referendum in the municipality;

2. Free connection with the office;

3. Direct link-dealing with the matter via the Internet;

4. e-Municipality-mobile application with the current information about the municipality;

5. Municipality supporting business development;

6. Fan page on Facebook-social media in the municipality;

7. Wireless internet access in the municipality;

8. Spatial information system in the municipality;

9. The ability to set up a page using the tools on the page;

10. Social consultations in the municipality.

Websites functionalities were evaluated using the binary method. If a certain feature was found, the page received value 1 and if it was the opposite the value was 0 . Functionality index of a page is defined as a sum of points obtained for each feature. The results of the research of existing municipal public administration offices websites show that under these circumstances they cannot function as platforms for participation. In this way, local communities are deprived of the opportunity to present their ideas and achievements in the social forum. Most of the 116 municipalities of the studied province have websites that do not meet the criteria for functionality. The situation is slightly better only with the spatial information system, which includes $80 \%$ of the municipalities. It is also significant that only $53 \%$ of municipalities support the development of business and entrepreneurship. This is quite strange, but it can be explained by errors in macroeconomic policy that stem from the lack of external resources for the development of this region. While the Warmia and Mazury Province is one of the poorest provinces in Poland, its unique landscape and natural values indicate the possibility of rapid development of tourism and power industry based on renewable energy sources.

ICT has largely contributed to the development of the private sector, while the public sector has fallen far behind and it has become the barrier of growth and economic development. This applies in particular to the public administration sector. Removing this asymmetry will require the implementation of wikinomics models in the public administration. For this purpose, it is necessary to transform the websites of municipal public administration offices into the wikinomics platforms for participation.

The websites of municipal offices in the Warmia and Mazury Province were subject to a four-fold research in 2009-2020. Sixteen website functionality criteria were considered [62]:

1. Website is updated on a regular basis;

2. The postal address of the office is included, directions are provided;

3. The office publishes chat lines and/or discussion lists for the citizens;

4. The structure of the office has been posted; 
5. Current information is published on a regular basis;

6. There is a possibility to search for necessary information;

7. A calendar of posts is published;

8. The user can fill and send a form online;

9. Other than Polish language versions are available;

10. Website provides icons that help the user to use the website;

11. The website address of the office is intuitive;

12. Archive exists;

13. A map of the municipality is published;

14. Tourist attractions are indicated;

15. Link to "digital office" provided;

16. Link to ePUAP (Electronic Platform of Public Administration Services) provided.

Website evaluation was made using the binary method. The functionality index of a webpage is defined as the sum of the points obtained for each feature of functionality. Then the percentage of municipalities in the surveyed province, which websites meet certain criteria, was calculated. The findings are presented in Figure 7. In line with the visible development trend, municipal offices are gradually increasing the functionality of their websites, however, there are still difficulties with meeting criteria 3, 8, 9 and 15.

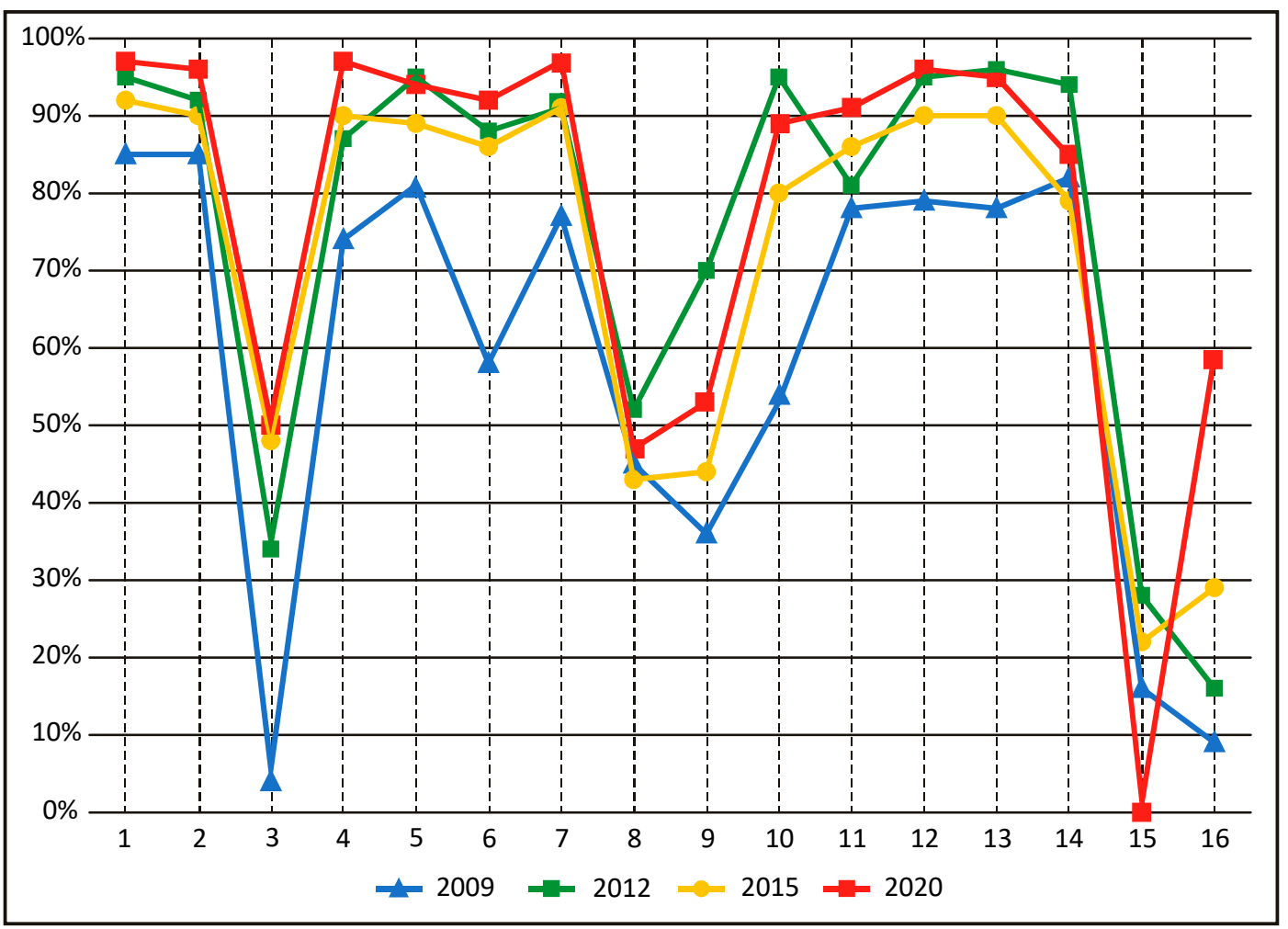

Figure 7. The percentage of websites of municipal offices which met the criteria of functionality in years 2009-2020.

\section{Principles of Economic Development of the Warmia and Mazury Province}

The Warmia and Mazury Province is the subject of study. It is one of the least economically developed provinces in Poland $[63,64]$. Therefore, municipal authorities as the basic units of the local government have the obligation to support entrepreneurship in their subordinate areas. According to the wikinomics, websites of municipal public administration offices should be the seeds of local growth poles that would focus economic forces operating in a given municipality. For this to happen, these websites should be transformed into platforms for participation, similar to platforms for commerce that have long existed in the market sector. Unfortunately, in the years 2010-2015 the level of information infrastructure 
in this province was low, however changes in the synthetic ICT index compared to its average value for the whole country indicated the occurrence of convergence (catching-up effect) [65]. An improvement in the situation should be expected in the coming years, as in 2015, the construction of the fiber-optic backbone distribution network with a length of $2292 \mathrm{~km}$ was completed in Warmia and Mazury, and its purpose is to provide residents, entrepreneurs and local authorities with access to broadband Internet. Some delays are associated with the need to build the last mile networks, that is, access networks that will connect retail end-users (customers) to the main network.

A negative phenomenon of shrinking can be observed in the municipalities of the Warmia and Mazury Province that results from adverse demographic changes. In the years 2012-2017, a decrease in the population was recorded in 95 municipalities out of all 116 in the province. This entails negative economic effects in the form of decreasing budgetary revenues of municipalities [40]. In such a situation, implementation of wikinomics business models in the public administration sector should be accelerated. As previous research shows, the society of Warmia and Mazury considers the implementation of prosumption principles in this sector to be highly desirable and rational [43]. The best way to achieve this would be through some form of public-private partnership, not limited to specific investment projects confirmed by the conclusion of formal contracts, but in the form of permanent, spontaneous cooperation between the public administration sector and the market sector. In such cases, the experience of the public partner would most likely decide on the success of the entire undertaking [66] (p. 516), which would indicate an additional argument for the need to transform the websites of municipal public administration offices into platforms for participation. In addition, the implementation of information technology would significantly contribute to the elimination of the sources of irrationality in the system of providing public administration services [53].

The most interesting initiatives conducive to the development of the digital economy include the accession of many cities of the Warmia and Mazury Province to the Polish National Cittàslow Network [67]. One of the goals of this organization is to improve the work of local administration and to adapt the functioning of the institution to the needs of residents. A step in the right direction is that some public administration offices receive notifications from the LocalSpot application, which allows residents to inform local government about issues in public spaces. This increases the chances of transforming municipal websites into platforms for grassroots action, which would include both platforms for public disclosure and platforms for neighborhood knowledge [9] (pp. 199-205).

\section{Digitization of the Public Administration Sector versus Historically and Politically} Conditioned Infrastructural Growth Poles and Development Axes

The impact of digitization of municipal public administration on the economic development of the Warmia and Mazury Province was studied in the period 2009-2019 [68]. For this purpose, an original method was used which consisted of the following steps:

1. The $k$-means algorithm was used to divide the websites of all municipal offices into four quality classes depending on the extent to which they served as participation platforms. Sixteen previously mentioned criteria were used. According to the assumptions of wikinomics, websites in the public administration sector become platforms for participation when they focus all economic forces operating in a given area and contribute to the socio-economic development of the municipality.

2. Each quality class of municipal websites has been assigned one of four distinct colors.

3. A map of the Warmia and Mazury Province was prepared, where all municipalities were marked with colors representing the quality classes of websites of public administration offices operating in their areas.

4. The map was used to plot a corresponding dual graph. Consequently, four such empirical dual graphs were created. 
5. The dual graph corresponding to the map of the province colored according to the conditions of the four-color theorem was the reference system for the evaluation of empirical graphs.

6. Digital growth poles and development axes were discovered on the basis of reduction of empirical dual graphs method. The reduction occurs when two neighboring municipalities have the same quality classes, which is interpreted as a manifestation of inter-municipal cooperation. The presence of an edge connecting adjacent municipalities signifies that there is no such cooperation.

7. The comparison of the spatial distribution of the quality classes of municipal websites with the general geographic database led to the discovery of a special feature of the province under study, which consists of the existence of politically and historically conditioned infrastructural growth poles and development axes.

The described method allowed not only to identify municipalities or their clusters, which form provincial growth engines, but also to develop a new measure of regional economic development. This measure ranges from 0 to 1 . A higher number indicates a more developed area. In the period 2009-2015, this indicator fluctuated reaching the values of $M_{D}^{2009}=0.7726, M_{D}^{2012}=0.8231$, and $M_{D}^{2015}=0.6173$, and only in 2019, a rapid increase to the value of $M_{D}^{2019}=0.7906$ was recorded. Fluctuations in the index indicate the cyclical development of the studied area. Another important finding was that the digital growth poles and development axes in the Warmia and Mazury Province are closely related to the existing road, rail and inland waterway infrastructure [69]. Historical conditions result from the fact that the present transport infrastructure has been shaped over the last several hundred years, and political conditions have their source in the complex history of statehood in Warmia and Mazury.

The beginnings of the economic development of these lands were associated with the use of renewable energy sources, mainly water and wind, to increase food production. The first windmills appeared in this area already in the 14th century and operated until the end of the first half of the 20th century. A little later, watermills started to operate with use of flowing rivers' energy. These devices replaced the previously used hand-mills, thus contributing to an increase in food production, which significantly accelerated local growth and economic development.

Current economic development of Warmia and Mazury should be viewed both through the prism of history and politics. In the years 1226-1466 the Monastic State of the Teutonic Knights ruled over the region. During the period, the entire flour milling industry was under a state monopoly. The production of flour was very profitable due to the compulsory grinding of grain legislation introduced by the authorities [70,71]. A peasant who wanted to grind the grain was forced to do it only in a specific mill and pay the fees charged for it. The use of hand-mills was prohibited. Violation of these regulations was punished with the confiscation of grain. As a result of the Second Peace of Thorn concluded in 1466, the State of the Teutonic Order was divided into Royal Prussia and Teutonic Prussia. The latter were renamed the Duchy of Prussia in 1525. Both parts of Prussia were functionally part of the Polish economy, with the Duchy of Prussia being a fiefdom relationship [72,73]. In 1772, after the First Partition of Poland, the territory of Warmia and Mazury was incorporated into East Prussia. As a result, the region became part of the Kingdom of Prussia, and then became part of the 19th century German Empire. The Potsdam Agreement, signed in 1945, split the East Prussia between Poland and the Soviet Union, owning to which Warmia and Mazury returned to Poland as part of the Recovered Territories.

The compulsory grinding of grain was abolished on 29 March 1808 by an edict issued by the Prussian king Frederick William III $[70,74]$. Since then, the number of mills has started to increase. According to historical sources, windmills in East Prussia accounted for $34 \%$ of all mills at the end of the 18th century [75] (p. 33). In the period from the sixteenth to the eighteenth century, milling was the most important industry in the Polish economy [75] (pp. 63-64). Wind and watermills were the first form of industrialization that appeared 
in Warmia and Mazury. Their location contributed to laying the foundations for today's transport infrastructure. This is due to the specificity of the operation of these mills as local industrial centers around which the economic life of that time concentrated. First, grain was brought in order to grind it, and then the finished product in the form of flour was exported. The placement of the roads used to transport grain and flour considered the geographic variation of the terrain by avoiding natural obstacles such as dense forests, wetlands, rivers, streams, lakes, hills, ravines and valleys. The roads were therefore optimal from an economic point of view. Today's roads and railway lines were drawn on the basis of the course of historical routes. It is along these lines that modern telecommunications infrastructure has been build, enabling residents to access the Internet. Therefore, the digital growth poles and development axes coincide with the transport network, indicating its critical contribution to the development of the region.

The theory of growth poles developed by François Perroux and the development axes concept proposed by Pierre Pottier occurred to be useful during the identification of growth factors using the quality class distribution method for websites of municipal public administration offices [76,77]. In general, growth poles are understood as propulsion units in the form of rapidly developing enterprises or sectors of the economy that facilitate the achievement of better economic results for other enterprises and industries in their environment. Contrastingly, according to the axis concept, economic development is transferred through communication routes and transport networks connecting the main industrial centers. According to wikinomics, a digital pole of growth is a website that uses advanced information technologies to support economic activity. The digital axis of development, however, is a series of digital growth poles located in space and cooperating with each other. The political history perfectly explains why the infrastructural axes of development identified by us in Warmia and Mazury are located mostly on the north-south line. Having considered the examined province from a functional point of view, it is easy to notice that it is a part of a much larger whole. The former Duchy of Prussia, which stretched much further to the north than the present territory of Warmia and Mazury, was in the years 1466-1657 part of the Crown of the Kingdom of Poland. Therefore, we are discussing an artificially limited area, which affects many of today's economic and social phenomena.

Figure 8 shows the location of the fiber-optic backbone distribution network, which is expected to make a significant contribution to the development of the low-emission economy in the Warmia and Mazury [78]. It is one of the largest recent investments in the region. It was implemented in the period 2008-2015, and its cost amounted to approximately 72,941,700 EUR. The total length of the network is $2292 \mathrm{~km}$ and its purpose is to enable access to broadband Internet for $91.8 \%$ of the region's inhabitants and all public institutions and enterprises. In the distribution layer it provides access with a bandwidth of at least $30 \mathrm{Mbit} / \mathrm{s}$, and in the backbone layer of at least $100 \mathrm{Gbit} / \mathrm{s}$, so NGA (Next Generation Access) requirements are met. The network consists of 216 distribution nodes, 10 backbone nodes, 2 higher-level fiber interconnection points and 2 network management centers $[79,80]$. General geographic features such as roads, railroads, built-up areas, forests, lakes, rivers and canals are also marked in Figure 8 in order to explain the complex shape of the network. As in the previous studies briefly described above, there is a relationship between the location of the network and the transport infrastructure that acts as growth poles and development axes. It should be emphasized that the region of Warmia and Mazury is very diverse in terms of terrain. There are over 3000 lakes, many rivers and streams, and more than a third of the province is forested. There are also many farmlands, hills, valleys and ravines. Communication routes have been designed in such a way as to avoid many natural obstacles. This leads to the conclusion that the complexity of the transport network is imposed by economic factors, which in turn is reflected in the distribution of the telecommunications infrastructure. 


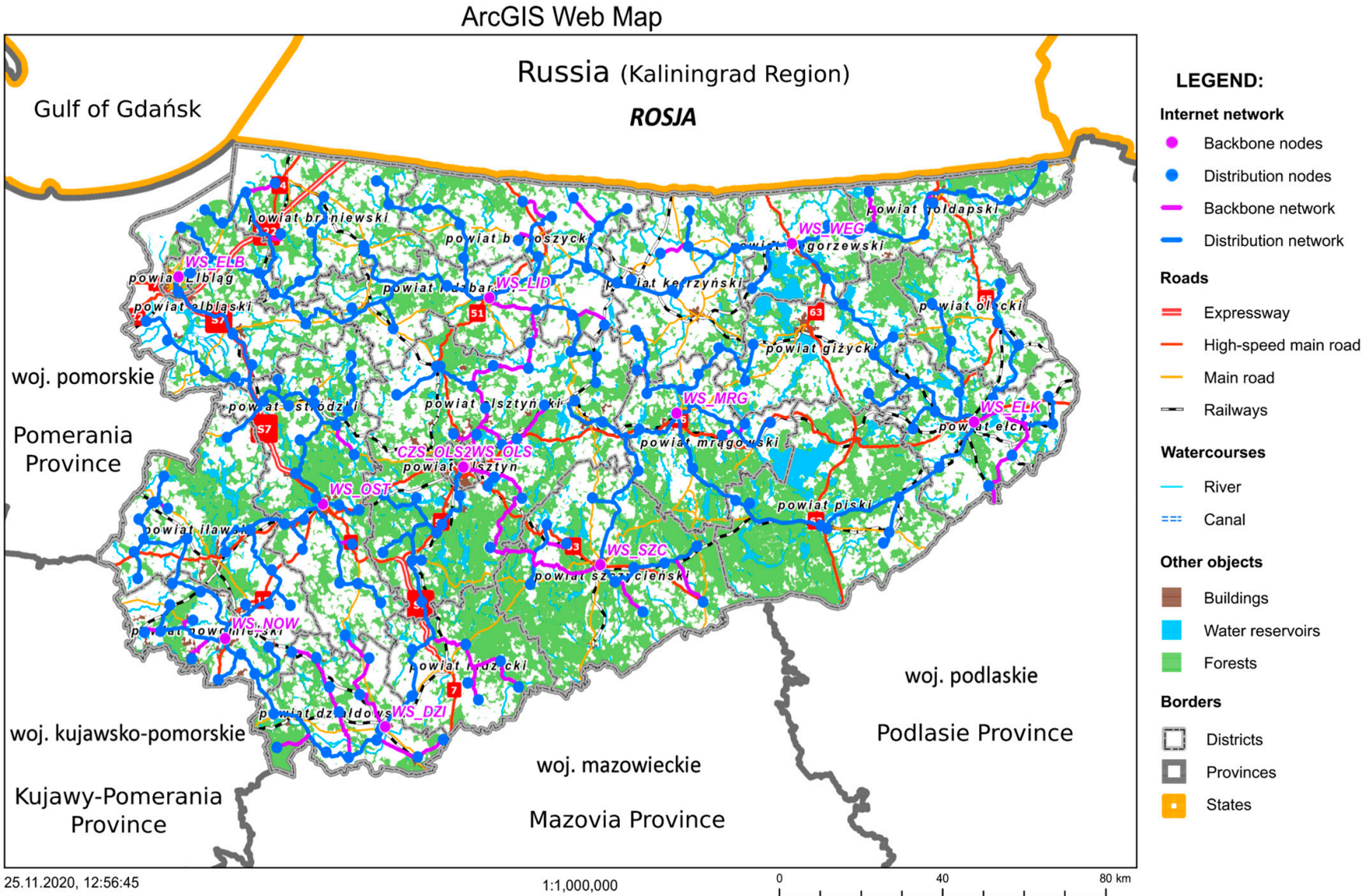

Figure 8. Map of the Warmia and Mazury Province showing the fiber-optic backbone distribution network, the main transport infrastructure and geographical diversity of the area.

Only half of the province's inhabitants had access to broadband Internet, before the construction of the fiber-optic computer network. Difficulties in this respect also concerned the public administration sector, as some municipal offices did not have websites at all. The creation of the fiber-optic backbone distribution network will not immediately increase the access to the Internet for all residents, institutions and enterprises, because the last-mile networks are still needed. The Digital Plan 2025 for Warmia and Mazury is the solution to this problem, as its purpose is the construction of the access networks connecting end subscribers with the main network $[81,82]$. This project aims to remove or reduce the economic barriers that hinder the construction of the last mile networks. As part of the plan, the fees for placing the telecommunications infrastructure along public roads were unified and reduced, and it was also exempted from the property tax. The main goal of the fiber-optic backbone distribution network and the related Digital Plan 2025 for Warmia and Mazury is to accelerate the socio-economic development of the region, support the lowemission economy and focus entrepreneurship on introducing new products and services to the market via the Internet. The expansion of computer networks is very important for the region's economy, as it will accelerate the modernization of existing enterprises and it will facilitate the introduction of new, innovative technologies.

The identification of historically and politically determined infrastructural growth poles on the basis of the quality classes of municipal websites is in fact a solution to an inverse problem. The starting point of the research was a set of information on quality classes, on the basis of which the causal factors necessary to generate the set were determined. In other words, the conclusions were started from the effects and then the causes were determined. Figure 8 shows a close, two-way cause and effect relationship between the location of transport infrastructure (road, rail and inland waterways) and the location 
of the fiber-optic backbone distribution network. Due to many natural obstacles in the form of lakes, rivers, streams, swamps, forests, hills, valleys, ravines, farmland, the telecommunications infrastructure was placed in the immediate vicinity of the transport network, which was a rational move, as it reduced the costs of the entire investment. Thus, Figure 8 confirms the conclusions obtained in previous studies, as it is a solution to a forward problem where effects are determined based on causes. We therefore have two sides to the same issue. Transport infrastructure facilitates the development of computer networks, and the latter accelerate the development of a low-carbon economy. Consequently, we are observing a positive feedback loop. Considering the location, IT networks in Warmia and Mazury are approximately a copy of the transport infrastructure.

\section{Barriers to the Development of Renewable Energy Sources in Warmia and Mazury Related to Environmental Protection, Tourism and Recreation}

The development of renewable energy sources in Warmia and Mazury is limited due to the need to protect the environment, a relatively large area of agricultural land, a large number of attractive tourist and recreational places and related infrastructure [83]. Figure 9 shows a map of the province under study, in which protected areas as well as tourist and recreational facilities are marked [84]. The areas valuable in terms of nature cover $46.7 \%$ of the region's area. They include 110 nature reserves, 8 landscape parks, 71 protected landscape areas, 34 Sites of Community Importance included in the Natura 2000 network, 10 special areas of habitat protection included in Natura 2000, 16 special areas of protection of birds belonging to Natura 2000. Moreover, 130 ecological sites, 15 nature and landscape complexes and one documentation site were established in order to protect the natural values of the region [85]. Furthermore, 4345 monuments of nature were distinguished, that is, legally protected natural or inanimate creations of special scientific, cultural, landscape and historical value.

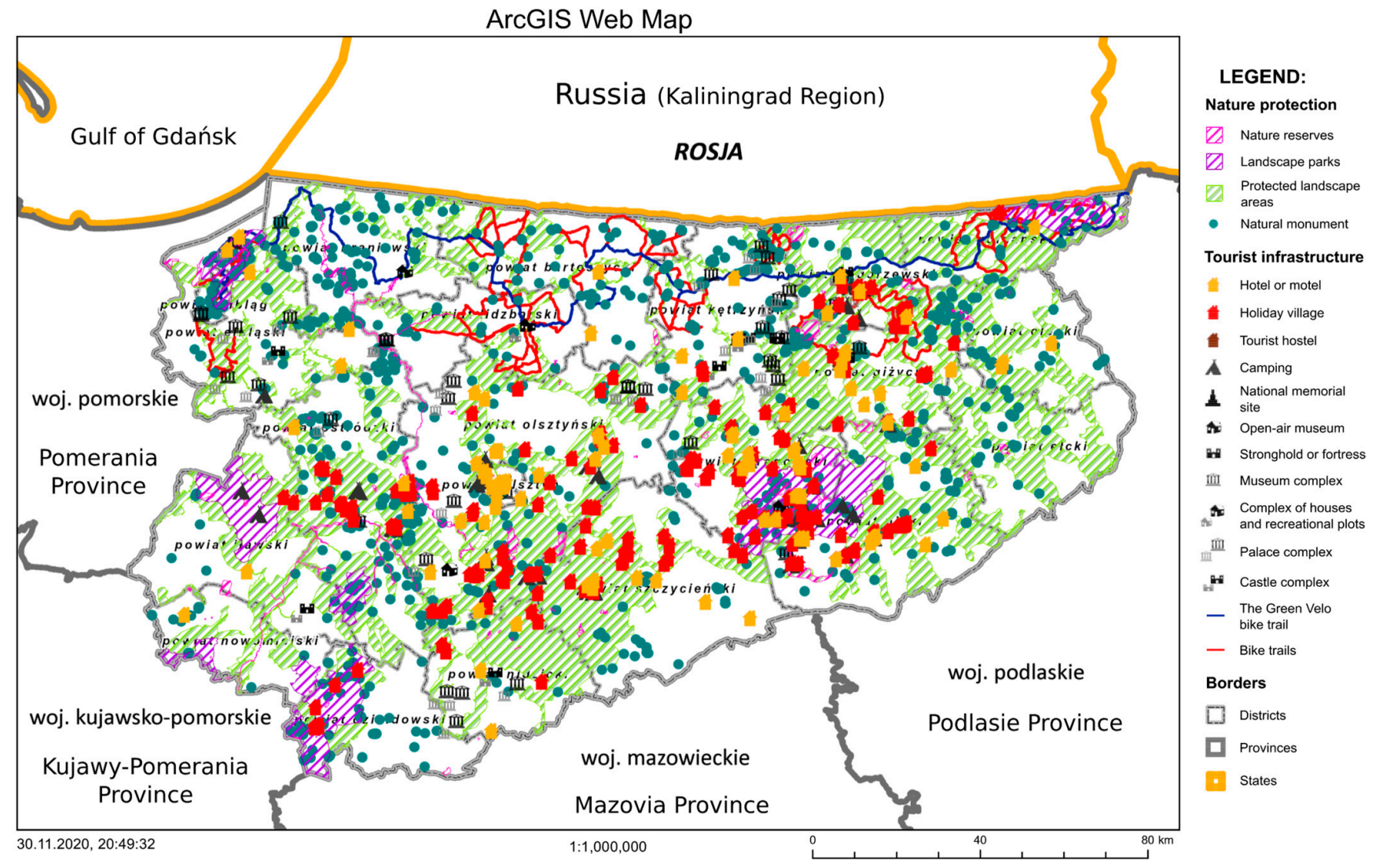

Figure 9. Protected nature sites and tourist infrastructure in the Warmia and Mazury Province. 
Figure 9 also shows areas related to tourism and recreation. There are many tourist facilities in the region, such as hotels, motels, recreation centers, tourist hostels, campsites, places of national remembrance, open-air folk museums, forts, fortresses, museum complexes, complexes of houses and recreational plots, castles and palace complexes. There are also many bicycle routes, which are more and more often built using the infrastructure remaining after disused railway lines [86]. Most of the tourist facilities are located in the south-eastern part of the province, mainly in the Land of the Great Masurian Lakes. The largest lakes in this region are Śniardwy and Mamry, with areas of $113.4 \mathrm{~km}^{2}$ and $102.8 \mathrm{~km}^{2}$, respectively. Many tourist facilities, such as hotels, motels and resorts, are concentrated in the area. Furthermore, in the northern part of Warmia and Mazury there are many bicycle paths, including the well-known Green Velo trail, which runs through the entire north-eastern Poland.

\section{Production of Energy from Renewable Sources in the Warmia and Mazury Province Compared to the Whole Country}

The following renewable energy sources are used in Poland: biogas, biomass, solar radiation, water and wind power. Table 6 shows the energy potential of renewable energy installations by provinces as of 31 December 2019 [87]. The list includes installations that have obtained a license to generate electricity, an entry in the register of energy producers in a small installation, an entry in the register of agricultural biogas producers, and micro-installations producing electricity covered by the system of certificates of origin or in the feed-in tariff system or operating according to auctions in support for renewable energy. Letter codes denoting individual energy sources are compliant with Table 7 . The installed capacity of all devices is $9106.248 \mathrm{MW}$ in total. Wind turbines have the largest installed capacity, 5917.243 MW, followed by biomass facilities-1492.875 MW, the next ones are hydropower installations-973.085 MW and solar power plants-477.679 MW. Generators using biogas have the lowest installed capacity, only 245.366 MW. As to the provinces, according to Table 6, the West Pomerania Province is in the first place in the use of renewable energy sources, with the installed capacity of $1675.828 \mathrm{MW}$, of which 1488.095 MW is wind energy. The Kujawy and Pomerania Province ranks second with a capacity of 1040.886 MW, of which 606.035 MW is wind energy. Next in line are the Greater Poland Province-942.765 MW and the Pomerania Province-784.791 MW, also based mainly on installations using wind energy, with capacities of 726.210 MW and 711.615 MW respectively. The lowest installed capacity, only $188.995 \mathrm{MW}$, is in the Opole Province. In the Warmia and Mazury Province, installations based on renewable energy sources have a capacity of $457.865 \mathrm{MW}$, and also here wind energy is most often used-356.985 MW.

In recent years, an upward trend has been observed in Poland in terms of the installed capacity of devices based on renewable energy sources. From 2015 to mid-2020, the capacity increased from 6970.033 MW to 9474.910 MW, with wind energy devices having the largest share. On the other hand, installations using solar radiation energy are developing the fastest, as their power in this period increased tenfold, that is, from $71.031 \mathrm{MW}$ to 708.019 MW. There is no spectacular increase in the power of devices using biogas and biomass, and in the case of facilities powered by hydropower there has even been a slight decrease [88].

In Poland, there is an alarming phenomenon of a gradual decrease in the amount of electricity generated from renewable sources, confirmed by certificates of origin issued by 30 June 2019. In the period 2015-2018, there was a decrease in the energy produced from 22,452,093.535 MWh to 19,351,928.202 MWh, mainly due to the decline in the use of hydropower and biomass. In contrast, power plants based on wind energy, solar radiation and biogas increased their production [89]. 
Table 6. Renewable energy installations in Poland as of 31 December 2019 (letter code in accordance with Table 7).

\begin{tabular}{|c|c|c|c|c|c|c|}
\hline \multirow{2}{*}{$\begin{array}{c}\text { Province } \\
\text { (Województwo) }\end{array}$} & \multicolumn{6}{|c|}{ Installed Capacity (MW) } \\
\hline & BG & BM & PVA & WIL & WO & Subtotal \\
\hline $\begin{array}{l}\text { Lower Silesia } \\
\text { (dolnośląskie) }\end{array}$ & 22.651 & 100.000 & 48.979 & 176.360 & 75.391 & 423.381 \\
\hline $\begin{array}{l}\text { Kujawy and } \\
\text { Pomerania } \\
\text { (kujawsko- } \\
\text { pomorskie) }\end{array}$ & 17.716 & 191.025 & 15.188 & 606.035 & 210.922 & 1040.886 \\
\hline Lublin (lubelskie) & 15.432 & 2.600 & 55.116 & 138.900 & 1.41 & 213.458 \\
\hline Lubusz (lubuskie) & 5.122 & 1.800 & 18.872 & 193.080 & 114.605 & 333.479 \\
\hline Lodz (łódzkie) & 12.491 & 59.26 & 43.609 & 580.969 & 11.07 & 707.399 \\
\hline $\begin{array}{l}\text { Lesser Poland } \\
\text { (małopolskie) }\end{array}$ & 10.623 & 16.900 & 9.305 & 5.932 & 185.38 & 228.140 \\
\hline $\begin{array}{c}\text { Mazovia } \\
\text { (mazowieckie) }\end{array}$ & 29.015 & 275.300 & 48.541 & 385.301 & 21.993 & 760.150 \\
\hline Opole (opolskie) & 3.949 & 0 & 13.993 & 140.900 & 30.153 & 188.995 \\
\hline $\begin{array}{l}\text { Podkarpackie } \\
\text { (podkarpackie) }\end{array}$ & 7.002 & 67.373 & 11.715 & 152.956 & 209.314 & 448.36 \\
\hline Podlasie (podlaskie) & 12.587 & 93.541 & 32.502 & 197.76 & 0.797 & 337.187 \\
\hline $\begin{array}{l}\text { Pomerania } \\
\text { (pomorskie) }\end{array}$ & 24.766 & 2.35 & 15.467 & 711.615 & 30.593 & 784.791 \\
\hline Silesia (śląskie) & 20.451 & 166.755 & 17.466 & 34.195 & 36.599 & 275.466 \\
\hline $\begin{array}{l}\text { Świętokrzyskie } \\
\text { (świętokrzyskie) }\end{array}$ & 3.822 & 243.214 & 16.373 & 21.95 & 2.739 & 288.098 \\
\hline $\begin{array}{l}\text { Warmia and Mazury } \\
\text { (warmińsko- } \\
\text { mazurskie) }\end{array}$ & 16.503 & 26.044 & 43.168 & 356.985 & 15.165 & 457.865 \\
\hline $\begin{array}{l}\text { Greater Poland } \\
\text { (wielkopolskie) }\end{array}$ & 26.568 & 141.662 & 35.737 & 726.210 & 12.588 & 942.765 \\
\hline $\begin{array}{l}\text { West Pomerania (za- } \\
\text { chodniopomorskie) }\end{array}$ & 16.668 & 105.051 & 51.648 & 1488.095 & 14.366 & 1675.828 \\
\hline Subtotal & 245.366 & 1492.875 & 477.679 & 5917.243 & 973.085 & 9106.248 \\
\hline
\end{tabular}

Table 7. Letter codes for types of renewable energy installations.

\begin{tabular}{cc}
\hline Letter Code & $\begin{array}{c}\text { Type of Renewable Energy Source } \\
\text { Installation }\end{array}$ \\
\hline BG & Using biogas \\
BM & Using biomass \\
PVA & Using the energy of solar radiation \\
WIL & Using wind energy \\
WO & Using hydropower \\
\hline
\end{tabular}

Electricity can also be produced in small power plants based on renewable energy sources. A small installation is understood as an installation of a renewable energy source with a total installed electrical power greater than $50 \mathrm{~kW}$ and lower than $500 \mathrm{~kW}$, connected to the power grid with a rated voltage lower than $110 \mathrm{kV}$ or with an achievable thermal power in combination greater than $150 \mathrm{~kW}$ but not greater than $900 \mathrm{~kW}$ with the total installed electrical capacity greater than $50 \mathrm{~kW}$ but lower than $500 \mathrm{~kW}$ [90].

Table 8 shows the number of small installation electricity producers in Poland, divided by renewable energy sources as of 31 December 2020 [91]. The largest number of small power plants was in Lodz and Lower Silesia Provinces, 89 and 88 respectively, and the least in the Lubusz and Kujawy and Pomerania Provinces, 18 and 23 respectively. Against this background, the Warmia and Mazury Province looks quite good, as the number of these producers is 64. Most installations use hydropower and solar radiation energy. At the end of 2019, the installed capacity of such installations was $162.8 \mathrm{MW}$, with the largest share 
for devices using waterpower and solar radiation, $51.5 \mathrm{MW}$ and $47.5 \mathrm{MW}$, respectively. Energy production in such installations increased from 176.6 GWh in 2016 to $342.6 \mathrm{GWh}$ in 2019. The greatest amount of electricity was produced in small hydropower plants. In 2016, water energy allowed the production of $90.4 \mathrm{GWh}$, and in 2019 it was already 158.00 GWh. Electricity production from sources such as non-agricultural biogas and wind is increasing in small installations. In the period 2018-2019, the amount of energy produced by photovoltaic systems decreased compared to the period 2016-2017 [92].

Table 8. Number of small installation electricity producers in Poland, divided by renewable energy sources as of 31 December 2020 (letter code in accordance with Table 7).

\begin{tabular}{|c|c|c|c|c|c|c|}
\hline \multirow{2}{*}{$\begin{array}{c}\text { Province } \\
\text { (Województwo) }\end{array}$} & \multicolumn{6}{|c|}{ Number of Electricity Producers } \\
\hline & BG * & BM & PVA & WIL & WO & Subtotal \\
\hline $\begin{array}{l}\text { Lower Silesia } \\
\text { (dolnośląskie) }\end{array}$ & 12 & 0 & 19 & 1 & 56 & 88 \\
\hline $\begin{array}{l}\text { Kujawy and } \\
\text { Pomerania } \\
\text { (kujawsko- } \\
\text { pomorskie) }\end{array}$ & 4 & 0 & 2 & 2 & 15 & 23 \\
\hline Lublin (lubelskie) & 5 & 0 & 40 & 2 & 7 & 54 \\
\hline Lubusz (lubuskie) & 3 & 0 & 7 & 1 & 7 & 18 \\
\hline Lodz (łódzkie) & 6 & 1 & 37 & 23 & 22 & 89 \\
\hline $\begin{array}{l}\text { Lesser Poland } \\
\text { (małopolskie) }\end{array}$ & 9 & 0 & 14 & 6 & 20 & 49 \\
\hline $\begin{array}{c}\text { Mazovia } \\
\text { (mazowieckie) }\end{array}$ & 16 & 0 & 22 & 10 & 16 & 64 \\
\hline Opole (opolskie) & 3 & 0 & 5 & 1 & 16 & 25 \\
\hline $\begin{array}{l}\text { Podkarpackie } \\
\text { (podkarpackie) }\end{array}$ & 7 & 0 & 29 & 10 & 6 & 52 \\
\hline Podlasie (podlaskie) & 4 & 0 & 19 & 0 & 5 & 28 \\
\hline $\begin{array}{l}\text { Pomerania } \\
\text { (pomorskie) }\end{array}$ & 5 & 0 & 8 & 4 & 50 & 67 \\
\hline Silesia (śląskie) & 20 & 1 & 37 & 6 & 15 & 79 \\
\hline $\begin{array}{l}\text { Świętokrzyskie } \\
\text { (świętokrzyskie) }\end{array}$ & 1 & 0 & 8 & 9 & 17 & 35 \\
\hline $\begin{array}{l}\text { Warmia and Mazury } \\
\text { (warmińsko- } \\
\text { mazurskie) }\end{array}$ & 2 & 0 & 16 & 2 & 44 & 64 \\
\hline $\begin{array}{l}\text { Greater Poland } \\
\text { (wielkopolskie) }\end{array}$ & 8 & 0 & 24 & 7 & 18 & 57 \\
\hline $\begin{array}{l}\text { West Pomerania (za- } \\
\text { chodniopomorskie) }\end{array}$ & 9 & 0 & 31 & 3 & 27 & 70 \\
\hline Subtotal & 114 & 2 & 318 & 87 & 341 & 862 \\
\hline
\end{tabular}

Table 9 presents the energy potential of renewable energy installations in the Warmia and Mazury Province by districts as of 31 December 2019 [87]. The total installed capacity of all devices was $457.865 \mathrm{MW}$, with wind and solar energy having the largest share, 356.985 MW and 43.168 MW, respectively. Water-powered devices had the lowest power, equal to 15.165 MW. Among the districts, the Iławski and the Ketrzyński districts have the greatest energy potential, with an installed capacity of $129.865 \mathrm{MW}$ and 75.464 MW, respectively. The lowest capacity for producing energy from renewable sources is in the Mragowski District-only 1.144 MW. The zeros appearing in Table 9 represent mostly unused energy potential in individual districts. Apart from hydropower, which can only be used under certain conditions, there are no major obstacles to the production of energy from other renewable sources. The smallest variation in the use of renewable energy sources is in the Piski District and the City of Elblag, where only one renewable energy source 
is used, solar radiation energy (6.874 MW) and biomass energy (25 MW), respectively. It is worth noting that biomass, apart from in the City of Elblag, is used only in the Ełcki District (0.824 MW) and in the Ostródzki District (0.220 MW). Moreover, over half of the districts do not use biogas. This is all the stranger, as the Warmia and Mazury Province has well-developed agriculture and forestry, which are natural sources of biomass and biogas. At the end of 2018, there were 10 agricultural biogas plants in this region, whose total technical capacity ranged from 29,647 to 43,238 thousand $\mathrm{m}^{3}$ /year, which is still a good result compared to the rest of the country [93]. Zeros or low numbers in Table 9 signify that individual districts and municipalities do not initiate the creation of installations using renewable energy sources at all or they are doing so insufficiently.

Table 9. Renewable energy installations in the Warmia and Mazury Province as of 31 December 2019 (letter code in accordance with Table 7).

\begin{tabular}{ccccccc}
\hline \multirow{2}{*}{$\begin{array}{c}\text { District } \\
\text { (Powiat) }\end{array}$} & BG & BM & PVA & WIL & WO & Subtotal \\
\cline { 2 - 7 } Bartoszycki & 0 & 0 & 1.704 & 0 & 0.110 & 1.814 \\
Braniewski & 0 & 0 & 1.998 & 26.000 & 3.558 & 31.556 \\
City of Elblag & 0 & 25 & 0 & 0 & 0 & 25.000 \\
City of & 0.702 & 0 & 0.200 & 0 & 0.91 & 1.812 \\
Olsztyn & 0 & 0 & 1.996 & 48.500 & 0.190 & 50.686 \\
Działdowski & 0 & 0 & 0 & 4.650 & 0.604 & 5.626 \\
Elblaski & 0.372 & 0.143 & 0.600 & 0.092 & 6.162 \\
Ełcki & 0.503 & 0.824 & 0.531 & 0.096 & 6.131 \\
Giżycki & 1.495 & 0 & 0.040 & 4.5 & 1.215 & 55.965 \\
Gołdapski & 0 & 0 & 1.270 & 53.48 & 0.076 & 129.865 \\
Iławski & 1.695 & 0 & 2.104 & 125.99 & 1.006 & 75.464 \\
Kętrzyński & 1.399 & 0 & 1.039 & 72.020 & 3.017 & 4.632 \\
Lidzbarski & 0 & 0 & 0.040 & 1.575 & 3.017 \\
Mraggowski & 0 & 0 & 1.100 & 0 & 0.044 & 1.144 \\
Nidzicki & 0 & 0 & 0.12 & 11.75 & 0 & 11.87 \\
Nowomiejski & 3.6 & 0 & 1.08 & 1.6 & 0.557 & 6.837 \\
Olecki & 2.263 & 0 & 2.506 & 4.6 & 0.141 & 9.510 \\
Olsztyński & 2.635 & 0 & 14.208 & 1.7 & 3.004 & 21.547 \\
Ostródzki & 1.839 & 0.220 & 0.127 & 0.020 & 0.090 & 2.296 \\
Piski & 0 & 0 & 6.874 & 0 & 0 & 6.874 \\
Szczycieński & 0 & 0 & 1.619 & 0 & 0.055 & 1.674 \\
Węgorzewski & 0 & 0 & 1.000 & 0 & 0.4 & 1.400 \\
\hline Subtotal & 16.503 & 26.044 & 43.168 & 356.985 & 15.165 & 457.865 \\
\hline
\end{tabular}

\section{Possibilities of Obtaining Electricity from Renewable Energy Sources in Warmia and Mazury}

In this part, the unused potential of Warmia and Mazury in the field of electricity production from renewable sources such as hydropower and wind energy will be analyzed. Geographical and natural conditions, the need to protect nature, as well as landscape and tourist values mean that renewable energy should be decentralized and be based on many small power plants used by local communities. Little-known economic facts critical to the development of small hydropower and wind power plants will be highlighted in this section. It has also been shown that molinology can be useful in the development of renewable energy. Discussion regarding the possibilities of using other energy sources in the form of biogas, biomass and solar radiation requires a separate study.

\subsection{The Energy Potential of Water}

A very large and so far underused potential in the field of electricity production is related to the use of water energy in the European Union countries. The EU project, Renewable Energy Sources Transforming Our Regions (RESTOR) Hydro, has catalogued inoperative and partially forgotten hydrotechnical facilities, such as historic mills, water 
wheels, inoperative hydropower stations, weirs and other lateral structures in rivers, that could be reused for the production of electricity in micro and small hydropower plants [94].

Table 10 presents the microhydro potential in Europe as of 3 January 2021, cataloged under the RESTOR Hydro project in the form of the number of facilities classified as unused hydrotechnical infrastructure in individual European Union countries [95]. The largest number of such unused devices is in France, where their number is 24,757, while Poland is in the second place, with 8560 such objects. Germany, Italy and Romania are next with the number of these sites equal to 5022,4863 , and 4396, respectively.

Table 10. Microhydro potential in Europe as of 3 January 2021, cataloged as part of the RESTOR Hydro project. Number of objects included in the unused hydrotechnical infrastructure that could constitute a material basis for the construction of micro and small hydropower plants (estimation of the lower limit with nameplate capacity: $68,780 \times 40 \mathrm{~kW}=2751.2 \mathrm{MW}$ ).

\begin{tabular}{cccccc}
\hline Countries & $\begin{array}{c}\text { Microhydro } \\
\text { Potential }\end{array}$ & Countries & $\begin{array}{c}\text { Microhydro } \\
\text { Potential }\end{array}$ & Countries & $\begin{array}{c}\text { Microhydro } \\
\text { Potential }\end{array}$ \\
\hline Austria & 772 & Germany & 5022 & Netherlands & 343 \\
Belgium & 2550 & Greece & 2935 & Poland & 8560 \\
Bulgaria & 887 & Hungary & 599 & Portugal & 143 \\
Cyprus & 2 & Ireland & 511 & Romania & 4396 \\
Czech & 1593 & Italy & 4863 & Slovakia & 101 \\
Republic & 290 & Latvia & 453 & Slovenia & 2017 \\
Denmark & 346 & Lithuania & 735 & Spain & 392 \\
Estonia & 1819 & Luxembourg & 118 & Sweden & 1927 \\
Finland & 24,757 & Malta & 4 & United & 2645 \\
France & & - & 15,240 & Kingdom & - \\
\hline Subtotal & 33,016 & & 68,780 & & 20,524 \\
\hline Total & & &
\end{tabular}

A total of 68,780 objects suitable for reconstruction have been marked on the map of Europe. If we assume that each facility would have a nameplate capacity of up to $40 \mathrm{~kW}$ of electricity, the total figure for all potential small hydropower plants in the European Union would sum up to $2751.2 \mathrm{MW}$. It should be emphasized that this is a careful estimate and in fact this number could be higher. This would allow for the closure of one of the largest coal-fired power plants in Germany-Jänschwalde Power Station (nameplate capacity $3000 \mathrm{MW}$ ) -with annual emissions in 2019 reaching $17.61 \mathrm{Mt} \mathrm{CO}_{2}$ (megatons of $\mathrm{CO}_{2}$ ). In the same year, the top ten polluters in Europe included as many as six German lignite power plants, which together emitted $93.47 \mathrm{Mt} \mathrm{CO}_{2}$ into the atmosphere. Among the top 10, there were only two Polish power plants-Bełchatów and Kozienice-with total emissions of $43.20 \mathrm{MtCO}_{2}$. Interestingly, the remaining polluters included the Swiss/Italian Mediterranean Shipping Company and the Irish airline Ryanair with emissions of 10.72 and $10.53 \mathrm{Mt} \mathrm{CO}_{2}$ respectively [96].

The RESTOR Hydro Map only has 68,780 fairly well-described remainders from hydrotechnical equipment; however, the project estimated that there are approximately 350,000 small installations powered by water energy across Europe that were built in the past. There is great potential in them, as they can constitute a material base facilitating the creation of a large number of micro and small hydroelectric power plants. Their employment would significantly reduce the costs of building such facilities. Including the estimated number of unused hydrotechnical facilities into the above calculation under the assumption of the nameplate capacity for each facility of $40 \mathrm{~kW}$, a total value of 14,000 MW could be achieved, which would allow for the closure of the three largest polluters in Europe, that is, the Bełchatów (Poland), Neurath (Germany), and Niederaußem (Germany) power plants, whose nameplate capacities are $5472 \mathrm{MW}, 4211 \mathrm{MW}$, and $3864 \mathrm{MW}$ 
respectively. Correspondent to data for 2019, this would reduce pollution by $73.77 \mathrm{Mt}$ $\mathrm{CO}_{2}$ [96].

According to some sources there are 16,005 dams in Poland that can be used to build mini and small hydropower plants. Their technical potential was estimated at 14.27 PJ (Petajoule). Following the same source, in 2018 there were 761 hydropower stations in the country, with $994 \mathrm{MW}$ of the total installed capacity, of which 746 were classified as small facilities [97]. The largest hydropower plant in Poland, using the energy of the Lower Vistula, is located in Włocławek. It uses six Kaplan hydro turbines, with the total installed power of 160.2 MW, which allows for producing electricity in the amount of $739 \mathrm{GWh} /$ year.

The Warmia and Mazury Province is situated in the lower section of the right-bank of the Vistula basin and in the left-bank of the Pregoła basin. The conditions for locating small hydropower plants are favorable due to the dense network of small rivers. The three rivers that have the greatest energy potential are: Łyna-4032 TJ/year, Drwęca-3384 TJ/year and Pasłeka-2196 TJ/year. This is a theoretical potential, while the practical potential may amount to as much as half of that. The potential of all other rivers in the region is approximately $4806 \mathrm{TJ} /$ year which is $50 \%$ of the potential of the three above-mentioned rivers [98].

Considering that, according to Table 9, the current energy potential of water in the Warmia and Mazury Province is $15.165 \mathrm{MW}$, and the number of small hydropower plants is 92 [98] (p. 47), the average installed capacity reaches the value of $164.837 \mathrm{~kW}$. The RESTOR Hydro project identified around 500 remains of former hydrotechnical facilities that could be used to build micro and small hydropower plants in the studied region. Under the careful assumption that the average installed capacity was $100 \mathrm{~kW}$, the energy potential of small hydropower plants would be $50 \mathrm{MW}$. Thus, the unused energy potential of water in Warmia and Mazury can be estimated at 50-15.165 = 34.835 MW. Assuming that the hydropower plant operates around $8000 \mathrm{~h} /$ year, the amount of additional energy that could be produced should be $278.680 \mathrm{GWh} /$ year. Meanwhile, the production of electricity from water in Warmia and Mazury in 2010 was only 49.177 GWh/year and this amount has not changed significantly to this day [98].

\subsection{Wind Energy Potential}

Figure 10 shows the wind map of the Warmia and Mazury Province with a division into municipalities, including wind energy zones, basic transport, road, rail and inland water infrastructure, as well as the location of former windmills operating in this area from the 18th to the 20th century. The numbers surrounding the map represent the wind energy in individual energy zones at a height of $30 \mathrm{~m}$ above ground level. The data needed to develop the map was collected by Professor Halina Lorenc from the Institute of Meteorology and Water Management-National Research Institute in Poland on the basis of measurements performed in the years 1971-2000 [99,100] (pp. 121-125), [101] (p. 20). A detailed description of wind energy zones is presented in Table 11.

Table 11. Description of wind energy zones given on the map (Figure 10).

\begin{tabular}{|c|c|c|}
\hline Zone Number and Name & $\begin{array}{c}\text { Wind Energy at a Height of } \\
10 \mathrm{~m}\left(\mathrm{kWh} / \mathrm{m}^{2} / \text { year }\right)\end{array}$ & $\begin{array}{l}\text { Wind Energy at a Height of } \\
30 \mathrm{~m}\left(\mathrm{kWh} / \mathrm{m}^{2} / \text { year }\right)\end{array}$ \\
\hline I-Extremely beneficial & $>1000$ & $>1500$ \\
\hline II-Very beneficial & $750-1000$ & $1000-1500$ \\
\hline III-Beneficial & $500-750$ & $750-1000$ \\
\hline IV-Not very favorable & $250-500$ & $500-750$ \\
\hline V-Very unfavorable* & $<250$ & $<500$ \\
\hline $\begin{array}{c}\text { VI-The top parts of the } \\
\text { mountains * }\end{array}$ & Excluded areas & Excluded areas \\
\hline
\end{tabular}

* Does not apply to the Warmia and Mazury Province. 


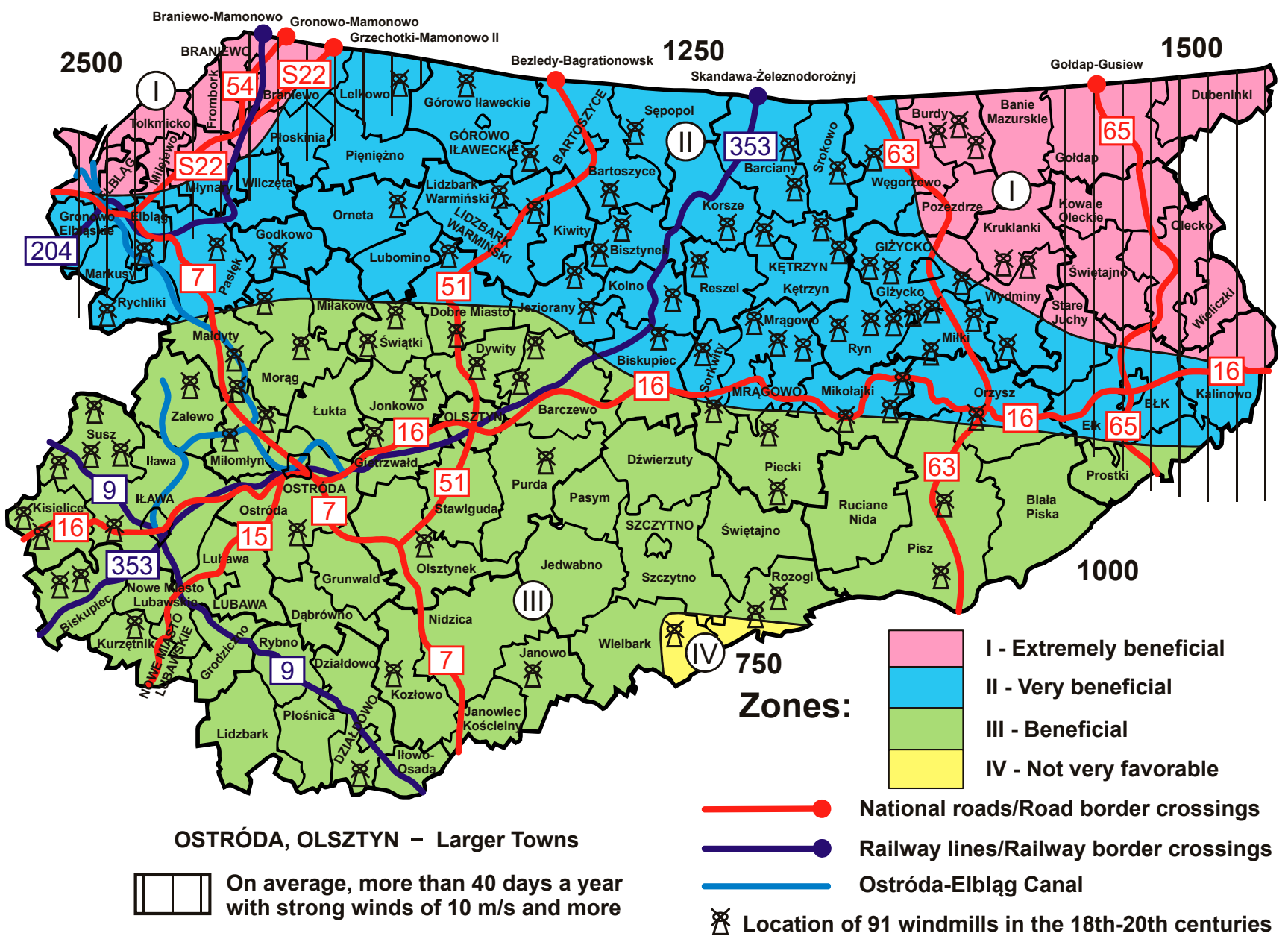

Figure 10. Wind map of the Warmia and Mazury Province with a division into municipalities with the indication of wind energy zones, transport infrastructure and the location of 91 former windmills.

The Warmia and Mazury Province is attractive for the development of wind power stations due to good wind conditions (Figure 10), large acreage of agricultural land, which is 1,100,000 ha, low population density, because only 59 people $/ \mathrm{km}^{2}$, and the presence of relatively large farms. Particularly, the orographically diverse and open areas of the region are suitable for the needs of wind power, that is, its north-eastern part. However, it should also be considered that winds with a maximum speed of gusts exceeding $11 \mathrm{~m} / \mathrm{s}$ at a height of $10 \mathrm{~m}$ and $30 \mathrm{~m}$ above the ground may occur in Warmia and Mazury [102]. This signifies a threat of a sharp increase in the turbulence of air streams which may be dangerous for people, wind turbines and the economy. A significant spatial limitation for the development of wind farms is the large area of protected areas, many of which belong to the Natura 2000 network (Figure 9). Moreover, a serious obstacle to the development of this form of electricity production is the poor technical condition of power networks, which limits the possibility of connecting new power plants to them. In Poland, distribution networks in rural areas are characterized by a high degree of failure, as a result of which over $50,000 \mathrm{~km}$ of medium voltage lines and over 150,000 km of low voltage lines throughout the country require immediate modernization. Additionally, the low density of these networks in northeastern Poland is also a problem [103]. Under these conditions, a substantial development of large wind energy is the subject of numerous controversies.

According to the position of the Provincial Parliament of 24 April 2012, support for wind energy is a very important factor in the sustainable development of the region, but the basic model should be based on small, home wind farms [104]. For this reason, two 
scenarios for the development of large wind energy in Warmia and Mazury have been adopted:

- Option A-ban on building of new power plants;

- Option B-increase in the installed capacity by approximately 250 MW by 2020.

As for variant $B$, the area requirements in the studied region were 10 hectares/MW, which with the planned $250 \mathrm{MW}$ increase of the nameplate capacity gives the space requirement of 2500 ha. This is about $0.1 \%$ of the surveyed province. It is possible to disagree with this calculation, because according to the opinion of the National Renewable Energy Laboratory, modern wind farms in the USA need about $34 \pm 22$ hectares/MW, which gives a capacity density equal to $3.0 \pm 1.7 \mathrm{MW} / \mathrm{km}^{2}$, so under certain conditions much more [105] (pp. 22-23). On 31 March 2013, 23 large wind power installations were operating in the region with a total nameplate capacity of 209.5 MW [98] (p. 41). Meanwhile, Table 9 shows that at the end of 2019, this capacity was only 356.985 MW. Therefore, the increase in power was only $147.485 \mathrm{MW}$, so the 2020 target has probably not been achieved. This shows that there is a greater number of Option A supporters in the provincial authorities.

Under these conditions, all emphasis has been shifted to the development of small wind farms with the nameplate capacity below $100 \mathrm{~kW}$. These types of wind turbines are intended for small and medium-sized businesses, farms and households. For a farm, the most profitable generator is about $10 \mathrm{KW}$. In 2010, there were 65,200 farms in the studied region [106], therefore assuming that one quarter of them, that is, 16,300 farms, would be interested in installing such a wind farm, an increase in the nameplate capacity by $163 \mathrm{MW}$ should be expected. However, nothing like that happened. Moreover, Table 8 shows that at the end of 2020 there were only 2 wind farms meeting the definition of a small installation in Warmia and Mazury, therefore the capacity that may be at stake ranges from $100 \mathrm{~kW}$ to $1 \mathrm{MW}$. This signifies that small wind power plants hardly develop in the studied region.

\subsection{Molinology versus Locations of Water and Wind Power Plants}

For the reasons discussed above, the Polish Ministry of Regional Development decided that the Warmia and Mazury region is indicated as a development zone for dispersed renewable wind and hydro power plants [107] (p. 30). In such a situation, economic entities, such as small and medium-sized enterprises, farms and even households, may be very interested in the criteria for selecting specific places that would be most suitable for the installation of small energy devices of this type. The achievements of molinology can be used to search for convenient locations for small hydro or wind power plants. Currently, this type of guidance is usually not available to prosumers who can only learn about the general planning aspects of the location of these types of power plants [108].

In the 1950s, Franciszek A. Klonowski, an outstanding Polish ethnographer and researcher of the folk culture of Warmia and Mazury, prepared a detailed inventory of watermills and windmills in this region $[109,110]$. One of his distinct achievements was the completion of a map of Warmia and Mazury, based on data from state archives and detailed field research, with the exact location of 91 windmills that operated in this area from the 18th to the first half of the 20th century. These mills are marked on the wind map presented in Figure 10. As it can be observed, most of them were located in what is today defined as places very beneficial for wind power stations. The question arises as to how the sites for the locations of such devices were selected, if a thorough meteorological research was not available several centuries ago. The answers are provided by ethnographic research and the history of the milling industry, which today combine into a science called molinology. In previous centuries, the exact location of watermills and windmills was established basing on the so-called water test [111] (p. 149), [112] (pp. 75-76). In order to perform the test, the builders who came to the site selected for the construction of the mill, poured nine measures of water (amounting approximately to nine modern shot glasses) into a glass decanter, and after blocking it, they buried it in the ground. The decanter stayed in the ground for nine days and nights, after which the designers unearthed it and measured 
the volume of water in the decanter. If the quantity increased by at least half of the used measure then the place was considered clean and fit for the construction of a mill. It seems that we are not necessarily dealing with any superstitions. The above phenomenon may be a symptom of some unknown law of physics or an unknown effect of the operation of an already known law. It should be emphasized that the case of obtaining raw material, mainly wood, for the construction of mills was similar until recently. This process was commonly regarded as a superstition. The rule was that the trees selected earlier in the forest had to be cut between the full moon and the new moon, that is, when the moon was waning, and it was necessary to do so in the winter months, and precisely in the period from mid-November to mid-February [112] (pp. 60-61). Today's science confirms that in this way it is possible to obtain the most durable material resistant to weather conditions and capable of surviving for hundreds of years $[113,114]$. Perhaps it is the quantum effects in wood that may be related in some way to the phases of the moon. Good location of the power plant is very important as it determines the economic profitability of the entire project.

\section{Discussion}

Wikinomics studies the changes in modern business models that result from the expansion of digital technologies in national economies. One of the main problems considered by wikinomics is the deepening asymmetry between the development of the market sector and the public administration sector. The aim of the study is to determine the degree of matching of the public administration sector to the market sector in Poland. This issue is of critical importance for the diversification of the production of energy from renewable sources in Warmia and Mazury. The analysis of the match between the two sectors has been carried out in accordance with the wikinomics guidelines, with emphasis on two business models: prosumption and platforms for participation. Therefore, it was the two-step study. In the first part a database of prosumption principles in public administration were used based on a direct survey conducted in 2015. Respondents were clients of municipal public administration offices in the Warmia and Mazury Province (north-eastern Poland). In the second part, the answer to the question is whether the web pages of municipal public administration offices meet the conditions of modern platforms for participation. The existence of such platforms is a prerequisite for the introduction of prosumption in public administration. The basic research method was the correspondence analysis, and the results were graphically presented in three-dimensional and two-dimensional charts. However, the websites of municipal public administration offices were evaluated by a binary method. In the course of research, it turned out that there are substantial difficulties in implementing the prosumption principles and platforms for participation in the public administration sphere. They are due to the lack of sufficient transparency of the public sector. This results in the absence of synchronization between the public sector and the market sector. The sources of problems are both technological and sociological factors. Moreover, the study showed that the region's inhabitants and entrepreneurs are ready to take up the challenge of shifting public administration to the prosumer model. They already have relevant prosumption experience from the market sector.

Presented by the authors the principles of prosumption are, according to respondents, a key factor in the development of public administration sphere in Poland. It is clear from Figures 3-6 that the way in which these principles are rated by women and men is slightly different, but their opinions are complementary. On all correspondence analysis plots, the sets of points form concentrated areas that are marked with colored ellipses. This means that respondents consider the presented principles to be critical for economic growth and development. In this way, the asymmetry between the wikinomics business models in private and public sectors can be overcome.

The introduction of a wider scale of the principles of prosumption to the public administration sphere will not be possible without transforming the municipal offices websites into platforms for participation. Figure 7 shows that the existing websites do not 
meet the wikinomics standards of functionality. Moreover, implementing reforms in the public administration sector also requires changing the existing model of its functioning towards greater openness.

The introduction of a digital prosumption model in public administration on a larger scale will certainly be a significant facilitation for prosumers enabling them to overcome all administrative barriers and launch the production of energy from renewable sources more quickly. It is estimated that in today's conditions it takes from two to five years to receive a permit to build a small hydropower plant and preferential bank loans are difficult to obtain. In the opinion of practitioners, the current situation in terms of the development of this type of installations is much worse than it was at the end of the 1980s, when the socialist economy still existed in Poland. It can be noticed that in the period 1982-1989, the economic conditions for these types of activities were very good. Distributed hydropower was supported by public administration offices, one could also count on the support of energy recipients mainly electrical companies. It was also possible to obtain preferential bank loans. This allowed for building transformer stations, repairing turbines and strengthening riverbanks [115]. Nowadays, digital public administration could make much more progress and significantly accelerate the development of energy production from renewable sources, which is a condition for the quick achievement of climate neutrality. The difficulties in introducing the prosumption model into public administration are currently reflected in the slow progress in the production of energy from renewable sources. As previously demonstrated [68], advanced websites of municipal offices can act as growth poles and create spatial development axes that could stimulate local economic growth under the terms of the Paris Agreement.

The above research shows that the Warmia and Mazury Province has a chance to achieve climate neutrality much faster than by 2050 and thus be able to overtake the rest of the country in this respect. Moreover, due to favorable natural conditions, mainly large forest areas absorbing $\mathrm{CO}_{2}$, this region may accelerate the achievement of this target for Poland. The main factor hampering the development of dispersed water and wind energy in this region is the unprogressive introduction of the prosumption model to public administration by local governments which affects many municipalities and districts. The swift completion of the last mile networks along with their connection to the fiber-optic backbone distribution network in order to create an integrated and modern information network throughout the province should be viewed as a critical prerequisite. This requires close cooperation between the local governments and local telecommunications operators and the elaboration of an appropriate model of public-private partnership.

The development of distributed energy in the province under study may, to some extent be an alternative to the costly repairs of medium and low voltage power grids with a length of hundreds of thousands of kilometers. Nevertheless, it should be possible for prosumers to sell the surplus of their renewable energy to cover shortages that might arise elsewhere.

In view of the increasing importance of prosumption in the modern world economy, a new form of capitalism emerges, the seed of which we have already observed todayprosumer capitalism $[116,117]$. Despite the undoubted social benefits that lie at its root, it can also pose some dangers. One is the exploitation of low-paid commodified workers and uncommodified prosumers, whose efforts are usually free-of-charge. This phenomenon can be one of the most important challenges facing the public administration sphere. In particular, this regards the enhanced exploitation of people known as synergistically double exploitation. According to its definition, prosumption covers the entire space between production and consumption, including the extreme points. Somewhere in the middle of this space we have what is called the balanced prosumption. However, in prosumer capitalism economic pressure is exerted on people to occupy places near the fringes at the same time. It is this phenomenon that is the source of synergistically double exploitation. It is observable at self-service gasoline stations, ATMs, self-checkouts at supermarkets, self-check-ins and self-checkouts at hotels, as well as in online stores. In all of these places, 
prosumers do unpaid work that was once done by paid workers. Thus, they are exploited as producers. Moreover, they are also exploited as consumers by overpaying for gasoline, bank services, foodstuffs, airplane tickets, hotel accommodations and online purchases. In prosumption capitalism, these two forms of exploitation interpenetrate [118]. Hence, adapting the public administration to modern economic conditions is a task that requires quick action.

In the case of the prosumption model applied to the diversification of production of energy from renewable sources, which is attempted to be implemented in the Warmia and Mazury Province, the phenomenon of synergistically double exploitation should not occur as intensely as in the above-mentioned situations. This is due to the fact that the prosumer can use either the entire or part of the energy he has produced for his own needs, thus gaining energy independence. In addition, and most importantly, it helps to contain global warming by reducing carbon dioxide emissions to the atmosphere. Finally, prosumers activities facilitate the achievement of climate neutrality, which can be a prerequisite for the survival of all humanity. Therefore, distributed production of renewable energy mitigates the negative traits of the existing form of capitalism.

\section{Conclusions}

In the Polish economy there is significant asymmetry between the private and public administration sector in terms of the absorption of the idea of the wikinomics. The biggest delay in the absorption of new ideas is in the public administration sector, which can hinder and delay the development of the private sector. It is urgent to include in procedures for the private and public administration sector management of new recommendations provided by the wikinomics business models. This will require greater transparency of the public sector in Poland. Websites of the municipal public administration offices do not meet the criteria required by the principles of prosumption, which can limit the country's economic potential both locally and nationally or internationally. This makes it impossible to introduce the ten proposed prosumption principles in the public administration sphere at both local and higher levels.

The findings contained in the article bode badly for the development of diversified production of energy from renewable sources in the Warmia and Mazury Province under the prosumer model. This is caused by too slow digitization of the public administration sector in this region and significant delays in achieving the assumed energy policy goals. There are many reasons for this, but the most important are the lack of sufficient economic incentives, persistent administrative and legal barriers and the lack of comprehensive solutions supporting prosumers. It should be emphasized that the achievement of climate neutrality in the studied region could be reached much earlier than in 2050, because there are rich resources of solar radiation, wind and water energy; moreover, there is a large number of farms and a huge area of forests, therefore raw materials for production of biomass and biogas are abundant. In addition, the region has the natural capacity to absorb carbon dioxide by forests, which classifies it as an important factor in achieving climate neutrality throughout the country. The Third Wave economy based on prosumption in the area of renewable energy sources can also reduce or weaken the threats of modern capitalism resulting from the phenomenon of synergistically double exploitation.

The commissioning of the backbone-distribution fiber optic network in 2015 and the gradual construction of access networks under the Digital Plan 2025 for Warmia and Mazury will certainly contribute to accelerating of the digitization of the public administration sector in the region. This should definitely accelerate the administrative activities related to starting and operating small hydro and wind power stations. For example, it currently takes two to five years to obtain a permit to build a small hydropower plant [115]. In such conditions it will be difficult to develop the renewable energy sector, so it is obvious that quick action is needed to improve public administration. The development of computer networks will also contribute to the modernization of existing enterprises, the implementation of innovative technologies in various sectors of the local economy and the 
orientation of entrepreneurship towards the development of new markets for products and services provided via the Internet.

The plans for the development of renewable energy in the Warmia and Mazur Province assume the construction of hydro and wind energy stations in a dispersed form. This region offers excellent conditions for the construction of small hydropower plants due to the dense network of rivers with a total energy potential of $14,418 \mathrm{TJ} /$ year. In addition, there are several hundred remains of former hydrotechnical facilities, which could significantly reduce the costs of building energy installations. The calculations in this article show that the current production of electricity from water-powered devices can be increased by at least $300 \mathrm{GWh}$ /year. Very good wind conditions in the examined province enable the construction of many small wind farms, each of which would have the nameplate capacity of about $100 \mathrm{~kW}$. There are over 60,000 farms in the region that could be interested in using this type of plant, but there is still no economic incentive to initiate this type of activity. However, the development of large wind farms is unlikely due to the presence of many threats to the natural environment.

An important issue related to the construction of small hydro and wind power plants is their exact location. For this purpose, molinology proves to be useful as it allows determination of the exact location of the ancient watermills and windmills. On the one hand, these are the remains of former hydrotechnical facilities, most of which can be reused, and on the other hand, we have detailed guidelines on where small wind farms can be built. In this way, it is possible to access unique knowledge regarding the properties of a given area. Moreover, it is easy to notice that the location of the old windmills is in line with the wind maps developed in modern times.

Nowadays, the cost of electricity production is no longer the main factor determining the choice of energy sources. This is due to the need to implement the Paris Agreement, which obliges the international community to reduce the global average temperature. Most often, power plants based on renewable energy sources, such as water or wind, are less profitable compared to obtaining electricity from fossil fuels. For example, in 2013 the levelized cost of electricity for lignite was $0.038-0.053$ Euro/ $\mathrm{kWh}$, for hard coal 0.063$0.080 \mathrm{Euro} / \mathrm{kWh}$, for onshore wind farms $0.045-0.107 \mathrm{Euro} / \mathrm{kWh}$, for photovoltaic systems 0.078-0.142 Euro/kWh and for biogas power plants 0.135-0.215 Euro/kWh [119] (p. 2). Moreover, solar and wind power plants have a lower efficiency than coal power plants, as they are more sensitive to weather changes, which was proved in the winter of 2020/2021 in Europe and the USA. Were it not for the need to reduce global warming, we would continue to use lignite as our primary energy source. Perhaps in the future the levelized cost of electricity will change as a result of the improvement of methods of obtaining electricity from renewable sources and the introduction of financial instruments favoring the development of green energy.

Considering the future of mankind, the use of renewable energy sources should be developed as soon as possible. Global warming is a threat that cannot be underestimated. Recent simulations based on computer models indicate that the Earth has already passed the point-of-no-return, irreversibly changing the dynamics of the climate system, which means that global warming cannot be stopped [120]. The reasons for this are the cycle of self-sustained thawing of the permafrost resulting from methane release, lower surface albedo due to melting ice and snow, and higher atmospheric humidity being the result of elevated temperatures. The process starts with global warming of just $+0.5^{\circ} \mathrm{C}$ above the pre-industrial level. Two scenarios are considered in the research. The first scenario assumes that man-made greenhouse gas emissions will be reduced to zero by the year 2100. Then the global average surface temperature will increase until approximately 2075 reaching a local maximum of $+2.3{ }^{\circ} \mathrm{C}$ above the pre-industrial times, then it will drop slightly and later will rise again steadily until 2500 when it will reach the value of $+3^{\circ} \mathrm{C}$. At the same time, by 2500 the sea level will rise $3.2 \mathrm{~m}$ above the level registered in 1850 . The second scenario assumed that emissions would be reduced to zero as early as 2020 . In this case, the global average surface temperature will slightly decrease to $+1^{\circ} \mathrm{C}$ by 2050 and 
will then rise steadily to around $+2.6{ }^{\circ} \mathrm{C}$ in 2500 . By contrast, ocean levels will continue to rise, albeit at a slower pace than in Scenario 1 and will be $2.5 \mathrm{~m}$ above pre-industrial times in 2500. It occurs that self-reinforcing thawing of the permafrost could only be avoided if man-made greenhouse gas emissions were reduced to zero between 1960 and 1970, when global warming was below $+0.5^{\circ} \mathrm{C}$. Currently, the situation can only be saved by the process of removing at least $33 \mathrm{GtCO}_{2} \mathrm{e}$ (a gigaton of carbon dioxide equivalent) from the atmosphere per year, starting from 2020. Thus, we return to the source of the problem identified almost four decades earlier in the movie Gwiezdny Pyt (Stardust), which makes it not only a very interesting element of film art, but also a visionary warning that cannot be ignored.

Author Contributions: Conceptualization, A.J. and D.R.; methodology, A.J. and D.R.; software, A.J. and D.R.; validation, A.J. and D.R.; formal analysis, A.J. and D.R.; investigation, A.J. and D.R.; resources, A.J. and D.R.; data curation, A.J. and D.R.; writing-original draft preparation, A.J. and D.R.; writing-review and editing, A.J. and D.R.; visualization, A.J. and D.R.; supervision, A.J. and D.R.; project administration, A.J. and D.R.; funding acquisition, A.J. and D.R. All authors have read and agreed to the published version of the manuscript.

Funding: This research received no external funding.

Institutional Review Board Statement: Not applicable.

Informed Consent Statement: Not applicable.

Data Availability Statement: Data is contained within the article.

Conflicts of Interest: The authors declare no conflict of interest.

\section{References}

1. Paris Agreement. 2016. Available online: https://eur-lex.europa.eu/legal-content/EN/TXT/?uri=uriserv\%3AOJ.L_.2016.282.01 .0004.01.ENG\&toc=OJ\%3AL\%3A2016\%3A282\%3AFULL (accessed on 22 January 2021).

2. United Nations Treaty Collection. Environment, Chapter XXVII, 7.d. Available online: https://treaties.un.org/pages/ViewDetails. aspx?src=TREATY\&mtdsg_no=XXVII-7-d\&chapter=27\&clang=_en (accessed on 10 February 2021).

3. Rząsa, D. Polska, z poparciem Czech, Węgier i Estonii, Zablokowała decyzję o dążeniu UE do Neutralności Klimatycznej do 2050 roku. 300Gospodarka. 2019. Available online: https://300gospodarka.pl/live/polska-z-poparciem-czech-wegier-i-estoniizablokowala-decyzje-o-dazeniu-ue-do-neutralnosci-klimatycznej-do-2050-roku (accessed on 7 December 2020).

4. EU Carbon Neutrality: Leaders Agree 2050 Target without Poland. BBC News. Available online: https://www.bbc.com/news / world-europe-50778001 (accessed on 24 January 2021).

5. Simon, F. Warsaw Says 'Committed' to EU's Climate Neutrality Goal. Available online: https://www.euractiv.com/section/ energy-environment/news/warsaw-says-committed-to-eus-climate-neutrality-goal/ (accessed on 15 December 2020).

6. Kondratiuk, A. Gwiezdny Pył (Stardust). Polish Drama Film; Przedsiębiorstwo Realizacji Filmów "Zespoły Filmowe”, Zespół Filmowy "Perspektywa" Warszawa, Poland. 1982. Available online: https:/ /www.youtube.com/watch?v=rqeXIuJekZ0 (accessed on 5 November 2020).

7. Smith, A. The Theory of Moral Sentiments; Haakonssen, K., Ed.; Cambridge University Press: New York, NY, USA, 2004; ISBN 0-521-59150-3.

8. Węglarz, A.; Winkowska, E.; Wójcik, W.; Kaul, M.; Goebel, K.; Schreiber, F.; Kind, C.; Peichert, H. Gospodarka Niskoemisyjna Zaczyna się w Gminie. Podręcznik dla Polskich Samorząów; Adelphi Research Gemeinnützige GmbH: Berlin, Germany, 2015.

9. Tapscott, D.; Williams, A.D. Wikinomics: How Mass Collaboration Changes Everything; Portfolio: New York, NY, USA, 2006; ISBN 978-1-59184-138-8.

10. Tapscott, D.; Williams, A.D. Macrowikinomics: Rebooting Business and the World; Portfolio/Penguin: New York, NY, USA, 2012; ISBN 978-1-59184-356-6.

11. Humphreys, A.; Grayson, K. The intersecting roles of consumer and producer: A critical perspective on co-production, co-creation and prosumption. Sociol. Compass 2008, 2, 963-980. [CrossRef]

12. Toffler, A. The Third Wave; William Morrow and Company: New York, NY, USA, 1980; ISBN 0-688-03597-3.

13. Toffler, A.; Toffler, H. Revolutionary Wealth: How It Will Be Created and How It Will Change Our Lives; Doubleday: New York, NY, USA, 2007; ISBN 978-0-385-52207-6.

14. Bajde, D.; Kos Koklic, M.; Bajde, J. Back to consumption and production? Prosumers negotiating the WMG lockdown on YouTube. J. Consum. Behav. 2015, 14, 297-306. [CrossRef]

15. Ziemba, E. (Ed.) Towards a Sustainable Information Society: People, Business and Public Administration Perspectives; Cambridge Scholars Publishing: Newcastle upon Tyne, UK, 2016; ISBN 978-1-4438-8688-8. 
16. Bouaziz, F. Public administration presence on the web: A cultural explanation. Electron. J. E-Gov. 2008, 6, 11-22. Available online: https:/ / academic-publishing.org/index.php/ejeg/article/view/480 (accessed on 15 January 2021).

17. Dusi, D. Investigating the exploitative and empowering potential of the prosumption phenomenon. Sociol. Compass 2017, 11, e12488. [CrossRef]

18. Jakimowicz, A. Wikinomiczne wzorce biznesowe w warunkach polskich. Studia i Prace WNEiZ US 2017, 47, 25-34. [CrossRef]

19. Olszański, H. Chłopskie Wiatraki Pogórza; Muzeum Budownictwa Ludowego w Sanoku: Sanok, Poland, 1976.

20. Olszański, H. Chtopskie Wiatraki Podkarpacia; Muzeum Budownictwa Ludowego w Sanoku: Sanok, Poland, 2002 ; ISBN 83-915210-0-1.

21. Roszko, J. Jak na Zawiszy. Reportaże z Sąecczyzny; Wydawnictwo Literackie: Kraków, Poland, 1971.

22. Kalkulator Inflacji. Wartość Nabywcza Złotówki. Available online: http:/ / banknotypolskie.pl/kalkulator (accessed on 24 January 2021).

23. Ziemnicka, K. Adam Słodowy i Fenomen Programu "Zrób to Sam". Available online: https:/ / film.interia.pl/telewizja/newsadam-slodowy-i-fenomen-programu-zrob-to-sam,nId,2300984 (accessed on 24 January 2021).

24. Jaraczewska, K. Adam Słodowy: Nasz Polski MacGyver. Available online: https://kobieta.interia.pl/show/news-adamslodowy-nasz-polski-macgyver,nId, 2349292 (accessed on 24 January 2021).

25. Słodowy, A. Lubię Majsterkować, 8th ed.; Wydawnictwa Naukowo-Techniczne: Warszawa, Poland, 1984.

26. Słodowy, A. Chcesz Samochód? "Zrób to Sam". Available online: http://www.auto-nostalgia.pl/wp-content/uploads/2013/12/ adam-s\%C5\%82odowy.jpg (accessed on 24 January 2021).

27. Słodowy, A. Budowa Samochodu Amatorskiego; Wydawnictwa Komunikacyjne: Warszawa, Poland, 1958.

28. Krasicki, A. Adam Słodowy, Czyli „Zrób to Sam”. Available online: https:// film.interia.pl/telewizja/news-adam-slodowy-czylizrob-to-sam,nId,1859999 (accessed on 24 January 2021).

29. Ponikowski, M. SAM, Czyli “Samochód Amatorski Motoru”. Available online: https://www.motofakty.pl/artykul/sam-czylisamochod-amatorski-motoru.html (accessed on 24 January 2021).

30. Ponikowski, M. Sam Zrób Sobie Samochód. Available online: https://www.motofakty.pl/artykul/sam-zrob-sobie-samochod. html (accessed on 24 January 2021).

31. Bierut, B. Sześcioletni Plan Odbudowy Warszawy; Książka i Wiedza: Warszawa, Poland, 1951.

32. Przykłady MEW (Małych Elektrowni Wodnych) Znajdujących się w Polsce. Available online: http://www.uwm.edu.pl/ kolektory/hydroenerget/mala/przykl..htm (accessed on 3 February 2021).

33. Turek, J. Jan Stach. Twórca Największego Kamiennego Mostu. Historia Prawdziwa; Wydawnictwo Poligraf: Brzezia Łąka, Poland, 2013; ISBN 978-83-7856-076-0.

34. Dobrowolski, R. The Bridge of Jan Stach. Polish Stone Magazine. 2013. Available online: http://swiat-kamienia.pl/index.php/pl/ home/288-english/news/2975-the-bridge-of-jan-stach (accessed on 24 January 2021).

35. Biegun, W. Największy Kamienny Most Zbudowany Przez Jednego Człowieka Jest w Polsce! Available online: https:/ / podroze. onet.pl/polska/malopolskie/most-jana-stacha-w-znamirowicach-nad-jeziorem-roznowskim/hp511ye (accessed on 25 January 2021).

36. Jaraczewski, J. Wznoszę Pomnik (I am Raising a Monument); Polish documentary; Wytwórnia Filmów Dokumentalnych; Warszawa, Poland. 1971. Available online: https:/ / www.youtube.com/watch?v=xhjSh8iH74U (accessed on 24 January 2021).

37. Wojciechowski, J. Nowoczesne Zabawki. Elektronika w Domu, Pracy, Szkole, 5th ed.; revised and supplemented; Wydawnictwa Komunikacji i Łaczności: Warszawa, Poland, 1974.

38. Gulik, E. Konsument, Prosument, Produser: Transformacja Podmiotu Wymiany Rynkowej w Społeczeństwie Sieci. Kultura $i$ Historia 2013, 24. Available online: http:/ / www.kulturaihistoria.umcs.lublin.pl/archives/5040 (accessed on 24 January 2021).

39. Igliński, B.; Buczkowski, R. Potencjał Techniczny i Możliwości Wykorzystania Biogazu Utylizacyjnego na Przykładzie Województwa Warmińsko-Mazurskiego. Rynek Energii 2017, 4, 56-62.

40. Wichowska, A. Shrinking municipalities and their budgetary revenues on the example of the Warmian-Masurian Voivodeship in Poland. Oeconomia Copernic. 2019, 10, 419-432. [CrossRef]

41. Polska Turbina Wodna Popłynie aż do Argentyny. Available online: https://www.gramwzielone.pl/trendy/33778/polskaturbina-wodna-poplynie-az-do-argentyny (accessed on 26 January 2021).

42. Bellon, M. Unia Odpuściła Polsce w Sprawie Klimatu. Możemy Stracić Miliardy. Available online: https://businessinsider.com. $\mathrm{pl} /$ finanse/neutralnosc-klimatyczna-do-2050-r-deklaracji-polski-brak-funduszy-bedzie-mniej/s01by6x (accessed on 25 January 2021).

43. Jakimowicz, A.; Rzeczkowski, D. Perspektywy realizacji zasad wikinomii w administracji publicznej w Polsce. Studia $i$ Prace WNEiZ US 2017, 47, 221-232. [CrossRef]

44. Benzécri, J.-P. Correspondence Analysis Handbook; CRC Press-Taylor \& Francis Group: Boca Raton, FL, USA, 1992; ISBN 978-08247-8437-9.

45. Greenacre, M.J. Theory and Applications of Correspondence Analysis; Academic Press: London, UK, 1984; ISBN 0-12-299050-1.

46. Greenacre, M.J.; Blasius, J. (Eds.) Correspondence Analysis in the Social Sciences: Recent Developments and Applications; Academic Press: London, UK, 1994; ISBN 0-12-104570-6.

47. Yelland, P.M. An introduction to correspondence analysis. Math. J. 2010, 12. [CrossRef]

48. Borg, I.; Groenen, P.J.F. Modern Multidimensional Scaling: Theory and Applications, 2nd ed.; Springer Science+Business Media: New York, NY, USA, 2005; ISBN 978-0387-25150-9. 
49. Greenacre, M.J. Correspondence Analysis in Practice, 3rd ed.; CRC Press-Taylor \& Francis Group: Boca Raton, FL, USA, 2017; ISBN 978-1-4987-3177-5.

50. Murtagh, F. Correspondence Analysis and Data Coding with Java and R; Chapman \& Hall/CRC-Taylor \& Francis Group: Boca Raton, FL, USA, 2005; ISBN 978-1-58488-528-3.

51. Stevens, S.S. On the theory of scales of measurement. Science 1946, 103, 677-680. [CrossRef]

52. Stevens, S.S. Psychophysics: Introduction to Its Perceptual, Neural, and Social Prospects; Routledge-Taylor \& Francis Group: New York, NY, USA, 2017; ISBN 978-0-88738-643-5.

53. Jakimowicz, A.; Rzeczkowski, D. Prosumption in the public administration sector. Acta Phys. Pol. A 2016, 129, 1011-1017. [CrossRef]

54. Jakimowicz, A.; Rzeczkowski, D. Diversification of innovation strategies of Polish industrial processing enterprises depending on their size after the global financial crisis. JEMI 2019, 15, 35-76. [CrossRef]

55. Jakimowicz, A.; Rzeczkowski, D. Do barriers to innovation impact changes in innovation activities of firms during business cycle? The effect of the Polish green island. Equilibrium 2019, 14, 631-676. [CrossRef]

56. Jakimowicz, A.; Rzeczkowski, D. Firm ownership and size versus innovation activities over the business cycle: Near-zero inertia as a sign of the transition from the fifth to the sixth Kondratieff wave. Oeconomia Copernic. 2019, 10, 689-741. [CrossRef]

57. Jakimowicz, A.; Rzeczkowski, D. Innovativeness of industrial processing enterprises and conjunctural movement. Entropy 2020, 22, 1177. [CrossRef] [PubMed]

58. Batyk, I.M.; Rzeczkowski, D. Cross-border cooperation at the external border of the European Union in the context of political, economic and social conditions: The case of the Polish-Russian neighbourhood. Equilibrium 2020, 15, 833-871. [CrossRef]

59. Agresti, A. Categorical Data Analysis, 3rd ed.; Wiley-Interscience-A John Wiley \& Sons: Hoboken, NJ, USA, 2013; ISBN 978-0-47046363-5.

60. Nenadić, O.; Greenacre, M. Correspondence analysis in R, with two- and three-dimensional graphics: The CA package. J. Stat. Softw. 2007, 20, 1-13. [CrossRef]

61. Greenacre, M.J. Biplots in Practice; Fundación BBVA: Bilbao, Spain, 2010; ISBN 978-84-923846-8-6.

62. Rzeczkowski, D. Potencjał Innowacyjności Sektora Administracji Publicznej; Wydawnictwo Naukowe PWN: Warsaw, Poland, 2014; ISBN 978-83-01-17459-0.

63. Czyżewska-Misztal, D.; Golejewska, A. The least innovative regions in Poland in the process of smart specialization. Optimum 2016, 5, 123-137. [CrossRef]

64. Kogut-Jaworska, M.; Ociepa-Kicińska, E. Smart specialisation as a strategy for implementing the regional innovation development policy-Poland case study. Sustainability 2020, 12, 7986. [CrossRef]

65. Wierzbicka, W. Information infrastructure as a pillar of the knowledge-based economy-An analysis of regional differentiation in Poland. Equilibrium 2018, 13, 123-139. [CrossRef]

66. Wegrzyn, J. Does experience exert impact on a public-private partnership performance? The case of Poland. Equilibrium 2018, 13, 509-522. [CrossRef]

67. Wierzbicka, W. Socio-economic potential of cities belonging to the Polish National Cittaslow Network. Oeconomia Copernic. 2020, 11, 203-224. [CrossRef]

68. Jakimowicz, A.; Rzeczkowski, D. New measure of economic development based on the four-colour theorem. Entropy 2021, 23, 61. [CrossRef]

69. Jakimowicz, A.; Rzeczkowski, D. Application of the four colour theorem to identify spatial regional poles and turnpikes of economic growth. Acta Phys. Pol. A 2018, 133, 1362-1370. [CrossRef]

70. Jasiński, J. Przemiany w zakresie przymusu mlewa na Warmii u schyłku XVIII i na początku XIX wieku. Komunikaty MazurskoWarmińskie 1965, 2, 229-242.

71. Chodkowska, W.; Sabljak-Olędzka, M. O Wiatrakach Warmii i Mazur i Młynarzu z Daleka...; Muzeum Budownictwa LudowegoPark Etnograficzny w Olsztynku: Olsztynek, Poland, 2016; ISBN 978-83-943479-4-9.

72. Małłek, J. Dwie Części Prus. Studia z Dziejów Prus Książęcych i Prus Królewskich w XVI i XVII Wieku; Wydawnictwo Pojezierze: Olsztyn, Poland, 1987; ISBN 83-7002-302-9.

73. Achremczyk, S. Historia Warmii i Mazur; Ośrodek Badań Naukowych im. Wojciecha Kętrzyńskiego w Olsztynie: Olsztyn, Poland, 2010-2011; Volume 1: Pradzieje-1772, ISBN 978-83-60839-33-1; Volume 2: 1772-2010, ISBN 978-83-60839-46-1.

74. Rzepkowski, K. Złoty Kciuk. Młyn i Młynarz w Kulturze Zachodu; Fundacja na rzecz Nauki Polskiej: Warszawa-Toruń, Poland, 2015; ISBN 978-83-941666-3-2.

75. Baranowski, B. Polskie Młynarstwo; Zakład Narodowy imienia Ossolińskich—Wydawnictwo: Wrocław-Warszawa, Poland, 1977.

76. Perroux, F. L'Économie du XXe Siècle; Presses Universitaires de France: Paris, France, 1964.

77. Pottier, P. Axes de communication et développement économique. Rev. Économique 1963, 14, 58-132. [CrossRef]

78. Sieć Szerokopasmowa Polski Wschodniej dla Województwa Warmińsko-Mazurskiego. Atlas Warmii i Mazur. System Informacji Przestrzennej. Available online: https:/ / atlas.warmia.mazury.pl/atlas/sieci/ (accessed on 25 November 2020).

79. Sieć Szerokopasmowa Polski Wschodniej. Regionalny Portal Informacyjny Wrota Warmii i Mazur. Available online: https:/ / www.warmia.mazury.pl/rozwoj-regionu/informatyzacja/158-siec-szerokopasmowa-polski-wschodniej (accessed on 17 January 2021). 
80. Krzyżanowski, P. Koniec Budowy Sieci Szerokopasmowej na Warmii i Mazurach. Komputer Świat. 2015. Available online: https: / / www.komputerswiat.pl/artykuly/redakcyjne/koniec-budowy-sieci-szerokopasmowej-na-warmii-i-mazurach/6pxxn4m (accessed on 18 January 2021).

81. Plan Cyfrowy 2025 dla Warmii i Mazur—Stan na 6 Marca 2017. Regionalny Portal Informacyjny Wrota Warmii i Mazur. Available online: https: / warmia.mazury.pl/rozwoj-regionu/informatyzacja/165-plan-cyfrowy-2025-dla-warmii-i-mazur-stan-na-6marca-2018 (accessed on 20 January 2020).

82. O Rozwoju Sieci „Ostatniej mili” na Warmii i Mazurach. Regionalny Portal Informacyjny Wrota Warmii i Mazur. Available online: https://warmia.mazury.pl/rozwoj-regionu/informatyzacja/162-o-rozwoju-sieci-ostatniej-mili-na-warmii-i-mazurach (accessed on 19 January 2021).

83. Batyk, I.M. Elektrownie wiatrowe czy krajobraz i turystyka. Studium przypadku. Infrastruktura i Ekologia Terenów Wiejskich 2012, 3, 27-36.

84. Turystyka i Rekreacja. Atlas Warmii i Mazur. System Informacji Przestrzennej. Available online: https://atlas.warmia.mazury.pl/ atlas/turystyka/ (accessed on 30 November 2020).

85. Formy Ochrony Przyrody. Regionalna Dyrekcja Ochrony Środowiska w Olsztynie. Available online: https://www.gov.pl/web/ rdos-olsztyn/formy-ochrony-przyrody (accessed on 10 February 2021).

86. Antolak, M.; Krawiecka, E. Możliwości wykorzystania nieczynnych linii kolejowych do rozwoju turystyki rowerowej w województwie warmińsko-mazurskim. Ekologia i Technika 2014, 22, 172-179.

87. Instalacje Odnawialnych Źródeł Energii Wg Stanu Na Dzień 31 Grudnia 2019 r. Available online: https://www.ure.gov.pl/pl/ oze/potencjal-krajowy-oze/8108,Instalacje-odnawialnych-zrodel-energii-wg-stanu-na-dzien-31-grudnia-2019-r.html (accessed on 20 January 2021).

88. Moc Zainstalowana (MW). Available online: https://www.ure.gov.pl/pl/oze/potencjal-krajowy-oze/5753,Moc-zainstalowanaMW.html (accessed on 25 January 2021).

89. Ilość Energii Elektrycznej Wytworzonej z OZE w Latach 2005-2019 Potwierdzonej Wydanymi Świadectwami Pochodzenia. Available online: https://www.ure.gov.pl/pl/oze/potencjal-krajowy-oze/5755,Ilosc-energii-elektrycznej-wytworzonej-z-OZEw-latach-2005-2019-potwierdzonej-wy.html (accessed on 24 January 2021).

90. Ustawa z Dnia 20 Lutego 2015 r. o Odnawialnych Źródłach Energii. In Dziennik Ustaw; 2015; poz. 478. Available online: http:/ / isap.sejm.gov.pl/isap.nsf/DocDetails.xsp?id=wdu20150000478 (accessed on 24 January 2021).

91. Rejestr Wytwórców Energii w Małej Instalacji-Stan Na Dzień 31.12.2020 r. Available online: https://bip.ure.gov.pl/bip/rejestryi-bazy / wytworcy-energii-w-male/2138, Rejestr-wytworcow-energii-w-malej-instalacji.html (accessed on 16 January 2021).

92. Wytwarzanie Energii Elektrycznej w Polsce w Małych Instalacjach OZE. Raport Prezesa URE za 2019 rok (Podstawa Prawna: Art. 17 Ustawy o Odnawialnych Źródłach Energii). Urząd Regulacji Energetyki, April 2020. Available online: https:/ /bip.ure.gov.pl/bip/o-urzedzie/zadania-prezesa-ure/raport-oze-art-17-ustaw/3556, Raport-zbiorcze-informacjedotyczace-wytwarzania-energii-elektrycznej-z-odnawial.html (accessed on 27 January 2021).

93. Piwowar, A. Agricultural biogas-An important element in the circular and low-carbon development in Poland. Energies 2020, 13, 1733. [CrossRef]

94. Unleash Microhydro Potential in Europe! Available online: http:/ / www.restor-hydro.eu/ (accessed on 4 January 2021).

95. Restor Hydro Map. Available online: http:/ / hydropower.kamilpiwowarski.pl/app (accessed on 3 January 2021).

96. Muzi, N. Top Shipping Polluter Overtakes Power Plants as Coal Shuts Down. Transport. Environment. 2020; Available online: https: / / www.transportenvironment.org/press/top-shipping-polluter-overtakes-power-plants-coal-shuts-down (accessed on 4 January 2021).

97. Igliński, B. Hydro energy in Poland: The history, current state, potential, SWOT analysis, environmental aspects. Int. J. Energy Water Resour. 2019, 3, 61-72. [CrossRef]

98. Копсерсја Rozwoju OZE w Województwie Warmińsko-Mazurskim do 2020 Roku; Warmińsko-Mazurska Agencja Energetyczna, Sp. z o.o. (LLC): Olsztyn, Poland, 2013; Available online: http:/ /www.wmae.pl/do-pobrania (accessed on 30 January 2021).

99. Niedźwiedź, T.; Paszyński, J.; Czekierda, D. Average annual number of days with strong wind ( $\geq 10 \mathrm{~m} / \mathrm{s})$. In Atlas of the Republic of Poland; Najgrakowski, M., Ed.; Surveyor General of Poland-Polish Academy of Sciences-Stanisław Leszczycki Institute of Geography and Spatial Organization: Warsaw, Poland, 1993-1997; board 31.6, map 14; ISBN 83-86339-00-4.

100. Lorenc, H. Struktura i Zasoby Energetyczne Wiatru w Polsce, Materiały Badawcze; Seria: Meteorologia-25; Instytut Meteorologii i Gospodarki Wodnej: Warszawa, Poland, 1996.

101. Lorenc, H. (Ed.) Atlas Klimatu Polski; Instytut Meteorologii i Gospodarki Wodnej: Warszawa, Poland, 2005; ISBN 83-88897-43-8.

102. Lorenc, H. Maksymalne Prędkości Wiatru w Polsce; Instytut Meteorologii i Gospodarki Wodnej—Państwowy Instytut Badawczy: Warszawa, Poland, 2012; ISBN 978-83-61102-62-5.

103. Koncepcja Przestrzennego Zagospodarowania Kraju 2030. Available online: http://www.wiki.leba.eu/strategie/strategia_ rozwoju_gminy?s[]=koncepcja (accessed on 30 January 2021).

104. Stanowisko Sejmiku Województwa Warmińsko-Mazurskiego z Dnia 24 Kwietnia 2012 r. w Sprawie Zasad Lokalizacji Obiektów Energetyki Wiatrowej w Województwie. Available online: http://kochamymazury.pl/stowarzyszenie/aktualnosci/24 -stanowisko-sejmiku.html (accessed on 31 January 2021).

105. Denholm, P.; Hand, M.; Jackson, M.; Ong, S. Land-Use Requirements of Modern Wind Power Plants in the United States. Technical Report NREL/TP-6A2-45834; National Renewable Energy Laboratory: Golden, CO, USA, 2009. 
106. Encyklopedia Warmii i Mazur: Gospodarstwo Rolne. Available online: http://encyklopedia.warmia.mazury.pl/index.php/ Gospodarstwo_rolne (accessed on 31 January 2021).

107. National Spatial Development Concept 2030. Summary of the Government Document Approved by the Council of Ministers on 13 December 2011. Ministry of Regional Development: Warsaw, Poland, 2012. Available online: https://www.msp-platform.eu/ practices/overarching-strategy-spatial-development-poland (accessed on 31 January 2021).

108. Gadomska, W.; Antolak, M. Selected planning aspects of the placement of wind farms in the Province of Warmia and Mazury. Architektura Krajobrazu 2014, 1, 102-113.

109. Klonowski, F.A. Z historii i inwentaryzacji wiatraków na Warmii, Mazurach i Powiślu. Rocznik Olsztyński 1958, 1, 193-222.

110. Klonowski, F.A. Z historii i inwentaryzacji młynów wodnych na Warmii, Mazurach i Powiślu. Rocznik Olsztyński 1959, 2, 173-193.

111. Kolberg, O. Dzieła Wszystkie; reedycja; Ludowa Spółdzielnia Wydawnicza-Polskie Wydawnictwo Muzyczne: Wrocław-Poznań, Poland, 1963; Volume 31, Part 3: Pokucie.

112. Adamczewski, J. Młynarstwo Magiczne; Polskie Towarzystwo Ludoznawcze: Wrocław, Poland, 2005; ISBN 83-87266-46-9.

113. Thoma, E. A Future with Natural Wood: Traditional \& Scientific Facts About Trees; Moontime Diary: Mullumbimby, Australia, 2015; ISBN 978-0-9873172-8-5.

114. Zürcher, E.; Rogenmoser, C. Considering Reversible Variations in Wood Properties: Possible Applications in the Choice of the Tree-Felling Date? In Proceedings of the International Convention of the Society of Wood Science and Technology and United Nations Economic Commission for Europe-Timber Committee, Geneva, Switzerland, 11-14 October 2010; Available online: https: / / arbor.bfh.ch/11607/ (accessed on 31 January 2021).

115. Kotłowski, R.; Szmidtke, L. Elektrownie Wodne-Dziś Trzeba Budować Od Podstaw. Pomorski Przegląd Gospodarczy 2013. Available online: https:/ /ppg.ibngr.pl/pomorski-przeglad-gospodarczy/elektrownie-wodne-dzis-trzeba-budowac-od-podstaw (accessed on 2 February 2021).

116. Ritzer, G.; Jurgenson, N. Production, consumption, prosumption: The nature of capitalism in the age of the digital 'prosumer'. J. Consum. Cult. 2010, 10, 13-36. [CrossRef]

117. Ritzer, G. The "new" world of prosumption: Evolution, "return of the same," or revolution? Sociol. Forum 2015, 30 , 1-17. [CrossRef]

118. Ritzer, G. Prosumption: Contemporary capitalism and the "new" prosumer. In The Oxford Handbook of Consumption; Wherry, F.F., Woodward, I., Eds.; Oxford University Press: New York, NY, USA, 2019; pp. 75-93. ISBN 9780190695583.

119. Kost, C.; Mayer, J.N.; Thomsen, J.; Hartmann, N.; Senkpiel, C.; Philipps, S.; Nold, S.; Lude, S.; Schlegl, T. Stromgestehungskosten Erneuerbare Energien. Studie_Version November 2013; Fraunhofer-Institut für Solare Energiesysteme ISE: Freiburg im Breisgau, Germany, 2013.

120. Randers, J.; Goluke, U. An earth system model shows self-sustained thawing of permafrost even if all man-made GHG emissions stop in 2020. Sci. Rep. 2020, 10, 18456. [CrossRef] [PubMed] 